\title{
HISTÓRIAS TERRITORIAIS: A PRIVATIZAÇÃO DAS TERRAS KAIOWA COMO ESTRATÉGIA PARA A GUARNIÇÃO DA FRONTEIRA BRASILEIRA E OUTRAS HISTÓRIAS ${ }^{1}$
}

KATYA VIETTA ${ }^{2}$

USP

\begin{abstract}
RESUMO: Entre os Kaiowa, o esboroamento de vínculos sociais, de práticas políticas, rituais e econômicas, gerador de miséria e violência, associa-se às perdas territoriais. Ponto de partida para uma pesquisa calcada na análise de histórias pessoais e familiares, onde o retrospecto de relações de parentesco, composições políticas, trocas rituais, deslocamentos e relações com não índios expôs consistentes histórias territoriais. Nelas, frágeis cronologias contrastam com etnografia e cartografia fartas. Esta, calcada na malha fluvial, traz chaves para ultrapassar a invisibilidade kaiowa ainda cultivada por historiadores e memorialistas. Neste contexto, o detalhamento da presença kaiowa na faixa de fronteira Brasil-Paraguai explicita o papel do Império/Estado brasileiro como gerador dos conflitos fundiários contemporâneos, na medida em que promoveu e apoiou projetos de colonização, forneceu títulos de propriedade - à revelia da presença indígena e da legislação vigente -, favoreceu a criação de oligarquias político/fundiárias, pontos de partida para as perdas territoriais kaiowa. Contudo, o entrelaçamento das narrativas indígenas e não indígenas não propõe uma etnohistória clássica, pois se as narrativas são complementares em seus conteúdos, são diversas quanto ao formato e as noções que abarcam.
\end{abstract}

PALAVRAS-CHAVE: Narrativa indígena; Território kaiowa; História kaiowa.

ABSTRACT: Among the Kaiowa, the downfall of political, ritualistic and economic practices, which generates misery and violence, is associated to territorial losses. That's the foundation to a research grounded on the analysis of personal and familiar stories, where the retrospect of kinship relations, politic composition, ritual exchanges, displacements and relationship with non indigenous led to a consistent territorial history. Within those, fragile chronologies contrast with a vast ethnography and cartography. This one is based on water courses, brings keys that surpasses the kaiowa invisibility, which is still cultivated by the historians and memorialists. In this context, the detailing of the kaiowa presence in the Brazil-Paraguay border demonstrates the role that the Brazilian Empire/State plays as a generator of contemporary land conflicts,

\footnotetext{
${ }^{1}$ Este artigo sintetiza análises apresentadas em Mesa Redonda promovida pelo Tribunal Popular da Terra/ MS, organizado a partir dos movimentos sociais e de direitos das populações indígenas e tradicionais (março de 2012), e no GT 15 Circunscrevendo fragmentos: debate sobre processos de reconhecimento de direitos territoriais século XXI, $28^{\mathrm{a}} \mathrm{RBA}$ (julho de 2012).

${ }^{2}$ Possui graduação em História pela Pontifícia Universidade Católica do Rio Grande do Sul (1986), mestrado em Antropologia Social pela Universidade Federal do Rio Grande do Sul (1992) e doutorado em Antropologia Social pela Universidade de São Paulo (2007). Tem experiência na área de Antropologia, com ênfase em Etnologia e História. Desenvolve assessoria às populações indígenas kaiowa, guarani e terena no Mato Grosso do Sul. E-mail: katya.vietta@gmail.com .
}

Espaço Ameríndio, Porto Alegre, v. 7, n. 2, p. 26-63, jul./dez. 2013. 
KATYA VIETTA - Histórias territoriais...

given that colonization projects and provided property titles - despite indigenous presence and legislation - support the establishment of political and territorial oligarchies, source of kaiowa land losses. However, the indigenous and non indigenous narratives' interlacement does not propose a classic ethno-history, because if the narratives are complementary in regard to contents, they differ in format and approaches.

PALAVRAS CHAVES: Indigenous narrative; Kaiowa land; Kaiowa history.

\section{As fontes, os métodos e outras abordagens}

Privilegiados pela oralidade, mas também pelo gosto em contar histórias, os Kaiowa facilmente expõem ricas narrativas dando conta de um amplo repertório de domínio público - como aquelas que explicam a criação da Terra, da humanidade -, ou tratando de experiências pessoais vividas ou ouvidas em outras histórias. Estas tendem a concentrar eventos mais ou menos recentes, onde os vínculos de parentesco entre personagens e narrador são facilmente explicitados. Embora representem um repertório de caráter mais familiar, elas podem percorrer um amplíssimo circuito de parentes ${ }^{3}$. O caminho a muito proposto por Sahlins (1990, 2001 e 2004), mostrou que as narrativas representam uma excelente ferramenta de pesquisa, enquanto instrumento privilegiado para organizar as experiências vividas e/ou ouvidas, e para expor as reflexões a respeito de si mesmo e dos povos com os quais convivem. As representações e as traduções interculturais, articulando história, política e cosmologia, dando conta de práticas e teorias sociais que permeiam as narrativas indígenas, também já foram discutidas por Gallois (1993, 2002 e 2007), Overing (1995) e Hill (1996 e 2002), entre outros.

Partindo desta perspectiva, a análise aqui proposta parte dos eventos relativos à experiência territorial dos Kaiowa que habitam as terras banhadas pelos rios Brilhante e Dourados no confronto com as frentes de exploração e colonização, invariavelmente propostas ou apoiadas pelo Império e depois pela República. A coleta de dados,

\footnotetext{
${ }^{3}$ A respeito da transmissão das narrativas e da periodização dos eventos nelas contido veja também Gallois (1993).
}

Espaço Ameríndio, Porto Alegre, v. 7, n. 2, p. 26-63, jul./dez. 2013. 
KATYA VIETTA - Histórias territoriais...

embora descontínua, teve início no final dos anos 1990. Entre seus objetivos estava compreender as transformações relativas às formas de organização político-ritual no contexto das drásticas reduções territoriais, e a relação destes fatos com questões contemporâneas desencadeadoras de diferentes níveis de violência individual e social. $O$ último século trouxe profundas transformações em todas as esferas da vida kaiowa, e a análise de determinados fatos contemporâneos precisa levar em conta esta perspectiva, a fim de desviar de eventuais rotas que conduzam a uma leitura simplificada ou artificial da realidade, especialmente no tocante a aspectos relativos às formas de organização social: composição das parentelas, relações de poder, práticas rituais, noções territoriais.

Há muitas décadas os Kaiowa reivindicam a demarcação de suas terras, o que contribui para a permanente atualização e ampliação da circulação de narrativas envolvendo conflitos e perdas territoriais que alcançam o período da guerra entre Brasil e Paraguai (1864-1870). Colocadas lado a lado, estas histórias compõem mosaicos capazes de explicitar com grande detalhamento os processos sociais e territoriais a que eles foram expostos. Parte significativa dos Kaiowa dominam tais temas, mas a interlocução privilegiada vem da parcela nascida na primeira metade do século $X X$, que teve a oportunidade de vivenciar os contatos ainda relativamente escassos com a população não indígena, quando habitava modelos de organização socioterritorial designados te'y jus ' $^{4}$, presentes ainda nos anos 1930-1940. Eles assistiram ao

\footnotetext{
${ }^{4} T e$ 'y: parentes; jusu: grande, muitos, de grandes proporções. Um grande conjunto de parentes. Alguns Kaiowa utilizam o termo tekoha guasu. Te'y jusu foi uma forma de organização socioterritorial bastante complexa, colocada sob a liderança político-ritual de um hexakara (xamã de maior destaque na hierarquia kaiowa) e composta por vários tekoha, formados por quatro a seis oygusu (casa grande) cada. Em tese, uma oygusu abrigava a liderança político-ritual familiar, sua(s) esposa(s), os filhos solteiros e os casados que conseguisse reter até a maturidade político-ritual, quando estes construíam a sua oygusu, junto à parentela do pai ou do sogro ou compunham o seu próprio tekoha. Nestes casos, não raro atraía um sogro cujos filhos já tivessem alcançado a maturidade político-ritual. Os cuidados na velhice exigem mais das filhas do que das noras. As alianças políticas se apoiavam em casamentos poligínicos - onde a poliginia sororal e o sororato aparecem como opções dignas de registro - e no grande número de descendentes deles originados. Apesar da descendência pela linha paterna angariar maior ênfase, o reconhecimento da descendência cognática alargava o leque de opções, enquanto um alto índice de casamentos endogâmicos fortalecia as relações entre os diversos tekoha de um te'y jusu. Entretanto, as alianças matrimoniais e a herança das funções políticas e rituais eram preferencialmente reguladas a partir da ordem de nascimento de filhos e filhas. Portanto, do ponto de vista social, os Kaiowa se organizavam a partir de grupos articulados pelas relações de consanguinidade e de afinidade, aglutinado através da habilidade política e xamânica de seu tekoahuvixa. A princípio toda liderança familiar é um mbohuvixa. Mbo: fazer, mandar, causar, principal; huvixa: aquele que está à frente. Porém uma liderança de tekoha se converte em
}

Espaço Ameríndio, Porto Alegre, v. 7, n. 2, p. 26-63, jul./dez. 2013. 
KATYA VIETTA - Histórias territoriais...

incremento dos processos de exploração e de colonização de seus territórios entregues a fazendeiros, sitiantes e mais recentemente disputados por projetos de urbanização. Aqui eventos e personagens são detalhadamente apresentados, oferecendo bons subsídios para a composição das genealogias destes e para a delimitação espacial daqueles, pois tendem a ser explicitados a partir da malha hidrográfica, compondo mapas impecáveis.

Há um distinto contraste entre o conteúdo das abordagens kaiowa e das abordagens produzidas por historiadores e memorialistas 5 . Aqui, a análise de conjunturas políticas, econômicas ou, ainda, dos feitos pessoais dos desbravadores - muitas vezes transformados em heróis regionais - ocorrem à revelia da presença indígena, geralmente secundária ou inexistente. Afirmar que tal invisibilidade contribui para negligenciar o lugar das populações indígenas no interior da história e da sociedade sul-mato-grossense é também apontar algo a respeito das práticas e teorias sociais explicitadas através das narrativas produzidas por estes segmentos de autores. Portanto, expor o protagonismo kaiowa é também conferir um novo significado a estas narrativas, mostrando que a invisibilidade kaiowa é o melhor argumento para discutir a sua presença.

tekoahuvixa, ou seja, aquele que está à frente do tekoha. Uma liderança de te'y jusu também pode ser tekoahuvixa ou tekoahuvixa guasu. Um te'y jusu apresentava um grande contingente populacional e uma forte estabilidade no tempo e no espaço, podendo permanecer por décadas em um mesmo espaço territorial. Contudo, os tekoha que o compunham produziam pequenos deslocamentos, motivados por interesses econômicos ou sociais, o que inclui a venda da mão de obra. A expressão teko pode ser traduzida por vida ou forma, maneira de viver, em uma acepção mais ampla, remete à ideia de cultura, porém todos os seres - humanos, animais, plantas - têm teko. Enquanto ha é traduzido por lugar, onde algo acontece. Assim, tekoha pode ser dito como: o lugar onde se vive, dado que remete à difundida definição de Melià (1985, 1987 e 1989; MELIÀ, GRÜNBERG e GRÜNBERG, 1976). Porém, penso tekoha e te'y jusu como noções mais inscritas nas relações sociais - que ocorrem em um espaço -, articulando elementos da ordem do parentesco, da economia, da ecologia, da cosmologia. Ver: Vietta (2007, cap. 4; 2012c; 2013, $1^{\mathrm{a}}$ e $2^{\mathrm{a}}$ partes), Pereira (1999, p. 201) e Almeida e Mura (2004).

${ }^{5}$ Memorialistas ou historiadores diletantes apresentam estudos muitas vezes criticados pelo seu viés ideológico, calcados na justificação da expropriação e da conquista, supervalorizando personagens e eventos políticos ligados às famílias reconhecidas como "desbravadoras dos sertões sul-matogrossenses", das quais muitas vezes estes escritores descendem. No entanto, justamente por esta inserção, eles têm acesso a narrativas e a documentos importantes, mesmo que nem sempre tais fontes sejam adequadamente tratadas ou estejam isentas da opinião pessoal do escritor. Neste contexto, é preciso acrescentar que as análises mais críticas da história local ganham ênfase apenas após a criação do estado do Mato Grosso do Sul, em 1977. Assim, muitos temas ainda carecem de um maior aprofundamento analítico, especialmente no tocante à inserção das populações indígenas nos processos de exploração econômica e de colonização da faixa de fronteira Brasil - Paraguai.

Espaço Ameríndio, Porto Alegre, v. 7, n. 2, p. 26-63, jul./dez. 2013. 
KATYA VIETTA - Histórias territoriais...

Embora tenha a intenção de colaborar com a discussão dos conteúdos colocados sob o título de história regional, não proponho exatamente uma análise de caráter etno-histórico. Constituindo diferentes abordagens a respeito dos mesmos eventos, narrativas indígenas e narrativas de historiadores podem até apresentar um caráter complementar, mas são distintas em suas construções e nas percepções que abarcam, aspectos que extrapolam as questões de conteúdo factual. Desta forma, as narrativas dos historiadores e/ou conteúdos retirados de outras documentações primárias escritas e as narrativas dos Kaiowa são tratadas como textos independentes. Este formato também permite expor a carga ideológica e emocional kaiowa ao tratar dos enfrentamentos com os não índios, desde a instalação dos conflitos fundiários, sempre carregados por alguma violência física e simbólica. Tais dados revelam muito das concepções destes índios a respeito deles mesmos e de seus opositores. O mesmo pode ser dito quanto às narrativas produzidas pelos historiadores, em especial pelos diletantes.

Por outro lado, a complementaridade dos textos permite compensar a fragilidade da cronologia apresentada nas narrativas kaiowa com as fartas datações oferecidas por historiadores e pela documentação primária, enquanto a malha hidrográfica - rota utilizada pelos Kaiowa, mas também pelos portugueses, espanhóis, brasileiros e paraguaios - permite o entrelaçamento de todos os conteúdos. Assim, os índios podem ganhar existência em ambos os discursos e todos os personagens podem dispor de nomes e histórias pessoais. Análises consistentes, bem documentadas e datadas são elementos que contribuem positivamente no contexto da consolidação, e principalmente para a conclusão satisfatória, dos processos demarcatórios, outro objetivo implícito neste tipo de pesquisa.

A dimensão e a profundidade do material compilado exige uma seleção dos resultados alcançados para dar sequência à discussão aqui apresentada6. Proponho uma análise sintética a partir de diferentes materiais produzidos por historiadores e memorialistas, além de documentação primária, compilados à luz das informações kaiowa; isto

\footnotetext{
${ }^{6}$ As análises foram apresentadas na íntegra em Vietta (2007, p. 27-270), revistas e ampliadas em Vietta (2011) e novamente revistas e ampliadas em 2013. As duas últimas estão voltadas para os processos demarcatórios. Uma abordagem apresentando de forma sintética a análise das narrativas kaiowa foi apresentada também em Vietta (2012c).
}

Espaço Ameríndio, Porto Alegre, v. 7, n. 2, p. 26-63, jul./dez. 2013. 
KATYA VIETTA - Histórias territoriais...

é, os resultados da pesquisa bibliográfica e documental orientada pelo conteúdo das narrativas kaiowa, com a intenção de fundamentar a argumentação a respeito de seus direitos fundiários. Sabemos que eventos envolvendo índios não costumam aparecer pormenorizados nas narrativas dos historiadores, mas também sabemos que portugueses, espanhóis, brasileiros e paraguaios, ao se envolverem em projetos de exploração e colonização, não se moveram por espaços vazios, como já se quis provar em muitas das teorias a respeito da conquista dos sertões, permanentemente atualizada por muitos memorialistas. Neste contexto é importante ressaltar que a contraposição do mapa da dispersão kaiowa, da legislação fundiária vigente e das ações de governo mostra que, invariavelmente, estas ocorreram à revelia dos direitos territoriais concedidos aos índios.

Os governos imperial e republicano, enquanto promotores ou apoiadores dos projetos de exploração e colonização das terras kaiowa, agiram na contramão da legislação vigente. Em terras sul-matogrossenses, este foi o principal recurso para garantir a ampliação e a posterior manutenção da faixa de fronteira, definitivamente conquistada através da guerra entre Brasil e Paraguai, levando à sistemática expulsão dos índios que nela viviam. Situação acirrada por expedientes governamentais visando à proteção dos novos ocupantes e de suas posses e a posterior regularização delas, muitas vezes envolvendo terras ainda habitadas por famílias indígenas. Por esta mesma via, a relação estabelecida entre latifúndio e poder político criou e consolidou oligarquias locais que seguiram sobrepujando os direitos territoriais indígenas.

\section{0 protagonismo kaiowa no contexto da história regional}

\subsection{Primeiras legislações fundiárias}

Apesar da legislação fundiária do Brasil Colônia ter sido baixada de modo descontínuo e fragmentário, as sesmarias ${ }^{7}$ - subdivisão

\footnotetext{
${ }^{7}$ Veja Nozoe (2006, p.588-589) e Diniz (2005). Conforme estes autores, o regime de sesmarias tem
}

Espaço Ameríndio, Porto Alegre, v. 7, n. 2, p. 26-63, jul./dez. 2013. 
KATYA VIETTA - Histórias territoriais...

proposta às capitanias hereditárias - constituíram o regime jurídico básico acerca da terra para o período. A sesmaria era uma cessão limitada no tempo e condicionada ao aproveitamento econômico das terras, as quais permaneciam sob o domínio público, ou seja, patrimônio da Coroa portuguesa, quem a distribuía conforme os seus interesses. Portanto, sesmeiros, assim como donatários, possuíam o usufruto, mas não a propriedade da terra, mesmo quando da produção de seu registro em paróquia. Lembrando que a união entre Coroa/Império/Estado e Igreja garantia aos párocos fazer os registros das terras, assim como de nascimentos, casamentos, óbitos, etc.

A fixação de limites e a obrigatoriedade do cultivo da terra eram responsabilidades de um sesmeiro. Para burlar esta segunda regra, criou-se a figura do pequeno lavrador ou posseiro, que adquiria terras através do arrendamento, aluguel ou compra. Relações fundiárias à margem do regime de sesmarias. Porém, gradativamente a Coroa passou a apoiar e beneficiar os posseiros como forma de limitar o poder do sesmeiro, bem como viabilizar a ocupação das terras em caráter produtivo $^{8}$ ou de defesa. Em decorrência da multiplicação de abusos, escândalos, pressões civis e litígios, a concessão de sesmarias foi suspensa em 1822, às vésperas da Independência e, portanto, da convocação da Assembleia Geral Constituinte. Até a publicação da lei $601 / 1850$, ou Lei de Terras, nenhuma norma voltada à regularização de terras foi criada. A necessidade de atender os interesses e a legitimação do novo Estado detentor de uma base social constituída por grandes proprietários, na maior parte, posseiros irregulares, relegou a discussão fundiária para o segundo plano9. Desta forma, entre as décadas de 1820 e 1850 a posse constituiu o principal modo de aquisição de terras em território brasileiro (NOZOE, 2006, p. 599-601).

Entre os dispositivos legais vigentes durante o regime de sesmarias, tem-se o reconhecimento da soberania e do direito dos

\footnotetext{
origem nas terras comunais medievais - communalia - lavradas e divididas em sesmos a serem sorteados entre seus lavradores, sendo transformado em instrumento legal no século XII, a fim de fomentar o cultivo das terras ermas, reconquistadas aos mouros ou deixadas ao abandono por conta do declínio da população rural dizimada pela peste negra ou rarefeita pelo êxodo em direção aos centros urbanos. Na Península Ibérica, o regime perdurou até o final do século XIII, mas posteriormente foi aplicado às terras portuguesas ultramar, na intenção de atrair colonos e garantir a produtividade das colônias.

${ }^{8}$ Veja Diniz (2005).

${ }^{9}$ Veja Guedes (2005, apud Nozoe, 2006, p. 601).
}

Espaço Ameríndio, Porto Alegre, v. 7, n. 2, p. 26-63, jul./dez. 2013. 
KATYA VIETTA - Histórias territoriais...

índios às terras por eles habitadas, instituído através das Cartas Régias de 30 de junho de 1609 e de 10 de setembro de 1611 , onde se afirma "o pleno domínio dos índios sobre seus territórios e sobre as terras que Ihe são alocadas nos aldeamentos" e que:

...os gentios são senhores de suas fazendas nas povoaçãos, como são na Serra, sem lhes poderem ser tomadas, nem sobre elles se Ihes fazer moléstia ou injustiça alguma; nem poderão ser mudados contra suas vontades das capitanias e lugares que Ihes forem ordenados, salvo quando elles livremente quizerem fazer... (apud CARNEIRO DA CUNHA, 1987, p. 58, sic).

Reafirmando e ampliando tais direitos, o Alvará Régio de 01 de abril de 1680 declarou que a cessão de sesmarias não poderia afetar os direitos originais dos índios às terras por eles habitadas, e que, como "primários e naturais senhores de suas terras", encontravam-se isentos de qualquer foro ou tributo ${ }^{10}$. Desde então, tal reconhecimento jurídico passa a ser, direta ou indiretamente, incorporado à legislação brasileira subsequente, constituindo o instituto do indigenato.

\subsection{A expansão e a consolidação da fronteira brasileira}

Enquanto isso, nas terras ao leste do rio Paraguai, há muito frequentadas por bandeirantes e jesuítas, durante os séculos XVIII e XIX se acirravam as disputas pela fronteira entre Brasil e Paraguai. A estratégia brasileira foi apoiar a ocupação do Sertão do Parnaíba, localizado entre os rios Aporé, Correntes, Pardo e Parnaíba, iniciada em 182811, que serviu de trampolim para a ocupação dos Campos de

\footnotetext{
10 "E para que os ditos Gentios, que assim decerem, e os mais, que há de presente, melhor se conservem nas Aldeias: hey por bem que senhores de suas fazendas, como o são no Sertão, sem lhe poderem ser tomadas, nem sobre ellas se lhe fazer moléstia. E o Governador com parecer dos ditos Religiosos assinará aos que descerem do Sertão, lugares convenientes para neles lavrarem, e cultivarem, e não poderão ser mudados dos ditos lugares contra sua vontade, nem serão obrigados a pagar foro, ou tributo algum das ditas terras, que ainda estejão dados em Sesmarias e pessoas particulares, porque na concessão destas se reserva sempre o prejuízo de terceiro, e muito mais se entende, e quero que se entenda ser reservado o prejuízo, e direito os Índios, primários e naturais senhores delas" (Alvará Régio de 01.04.1680, parágrafo $4^{\circ}$, apud CARNEIRO DA CUNHA, 1987, p. 59).

${ }^{11}$ A ocupação do Sertão de Parnaíba (ou Sertão dos Garcia) se sustentou pelos esforços do capitão José Garcia Leal, nomeado delegado do governo provincial de Mato Grosso para a exploração dos sertões. Joaquim Francisco Lopes, sertanista inicialmente financiado pelo governo provincial, mas igualmente
}

Espaço Ameríndio, Porto Alegre, v. 7, n. 2, p. 26-63, jul./dez. 2013. 
KATYA VIETTA - Histórias territoriais...

Vacaria, banhados pelas bacias dos rios Brilhante e Dourados, e da borda do Pantanal, banhada pelos rios Miranda, Aquidauana e Nioaque ${ }^{12}$. As novas fazendas se apoiaram largamente na facilidade para a obtenção de posses de terras e na preia de gado bovino semisselvagem, oriundo das frustradas tentativas de ocupação espanhola através da cidade de Santiago de Xerez e das Missões Jesuíticas do Itatim nos séculos XVI e XVII (ESSELIN, 2003, p. 12-15), bons atrativos para os exploradores que se propunham a correr os riscos de buscar prosperidade em terras de conflito internacional.

A identificação das rotas fluviais em direção ao rio Paraguai e a localização de posses eram objetivos de uma série de expedições lideradas pelos irmãos José, Gabriel e Joaquim Francisco Lopes. Empreita apoiada e financiada pela província do Mato Grosso e pelo império brasileiro, por iniciativa de José Saturnino da Costa Pereira. Costa Pereira foi presidente da província do Mato Grosso (1825-1828), senador do império (1828-1852) e ministro da guerra (1835-1837). Em 1839 os irmãos Francisco Lopes e os irmãos Antonio e Ignácio Gonçalves Barbosa - famílias unidas pelas núpcias de uma filha de Antonio com Gabriel e depois José - consolidaram as primeiras fazendas nos Campos de Vacaria. As suas posses abarcavam terras hoje divididas pelos municípios de Rio Brilhante, Nova Alvorada, Maracaju, Bela Vista, Jardim, Guia Lopes da Laguna, Nioaque e Sidrolândia. Mas eles também "tomaram" e negociaram posses para outros exploradores $^{13}$. A ausência de uma legislação reguladora para o acesso à terra rotinizava procedimentos deste tipo. No caso em pauta, ainda havia o largo apoio do governo imperial, que se beneficiava da infraestrutura consolidada pelos irmãos Lopes e Barbosa para ampliar a exploração e ocupação, inclusive militar, da faixa de fronteira.

\footnotetext{
apoiado nos novos fazendeiros locais e no governo imperial, garantiu a aquisição de posses tanto no Sertão dos Garcia como nos Campos de Vacaria - Ver: Camargo (2010, p. 74-145) e Lopes et al (2007). Seu irmão Gabriel Francisco Lopes, apoiado pelo sogro, Antonio Gonçalves Barbosa, também percorreu estas e outras rotas. Para estes temas veja também Almeida (2010, p. 41-50).

${ }^{12}$ Entretanto a ocupação da borda do Pantanal se inicia anos antes, em decorrência do exílio político de um grupo de cuiabanos associados ao levante denominado Rusga. A respeito destas frentes de ocupação, Ver: Queiroz (2008, p.20-23), Almeida (2010), Lopes et al (2007), Camargo (2010, p.90-105; 2011, p.56) e Guimarães (1999, p. 73-75).

13 Ver: Esselin (2003), Almeida (2010), Lopes (2007), Guimarães (1992 e 1999), Monteiro (2003), Rodrigues (1984), Wissenbach (1995), Dalmolin (2011) e Garcia Barbosa (2011a).
}

Espaço Ameríndio, Porto Alegre, v. 7, n. 2, p. 26-63, jul./dez. 2013. 


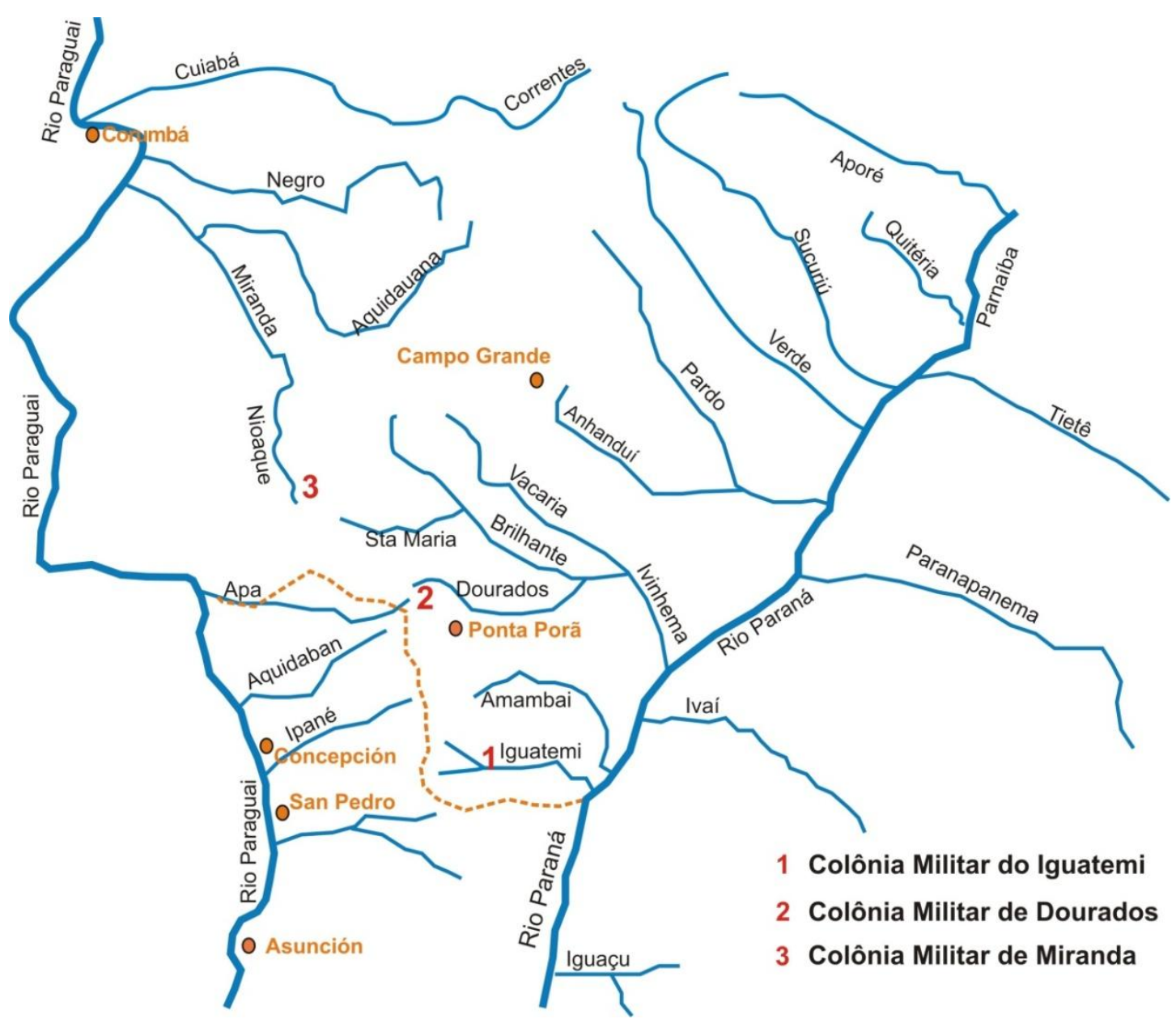

Figura 01: Rotas Hidrográficas e Colônias Militares Fonte: Guimarães 1999, mapa encarte.

Entre os inúmeros beneficiados pelas explorações dos Lopes está o barão de Antonina, um fazendeiro que iniciou na lida com gado como tropeiro, tornou-se deputado pela província de São Paulo em 1835, barão em 1843 e senador pela recém-criada província do Paraná em 1854, além de ser um sócio bastante atuante do Instituto Histórico e Geográfico Brasileiro (IHGB) ${ }^{14}$. Em 1842, Antonina solicitou o apoio do império para instalar aldeamentos indígenas voltados à catequese e à

\footnotetext{
${ }^{14}$ A respeito da biografia do Barão de Antonina, ver: Rodrigues (1984, p. 99), Amoroso (1998, p. 51-52) e Wissenbach (1995, p. 139-40). A associação ao IHGB rendeu a publicação de diversos registros das expedições promovidas pelo barão de Antonina, comandadas por Lopes e Elliot. Elliot foi cartógrafo e agrimensor (ROSA, 2004, p. 35). De acordo com T. Bigg-Wither, antes de se fixar no vale do Tibagi, ele atuou na marinha norte-americana (AMOROSO, 1998, p. 54).
}

Espaço Ameríndio, Porto Alegre, v. 7, n. 2, p. 26-63, jul./dez. 2013. 
KATYA VIETTA - Histórias territoriais...

civilização ${ }^{15}$, desencadeando a criação de aldeamentos associados a colônias militares ao longo da bacia do rio Paraná, eixo de comunicação entre as províncias de São Paulo, Paraná e Mato Grosso. O esforço do governo mostrava que a política indigenista voltava-se menos à catequese e mais ao suporte para a fronteira em conflito. As verbas destinadas aos aldeamentos também serviram para construir estradas para Antonina agilizar o comércio de seu gado (AMOROSO, 1998, p. 41-45). Uma das bases do projeto de catequese e civilização, as expedições chefiadas por Lopes e Elliot buscavam: identificar caminhos fluviais a partir do rio Paraná; localizar e registrar posses em nome de Antonina; atrair os povos de língua guarani para os aldeamentos. Lopes e Elliot registraram a presença destes índios desde os rios Vacaria, Paraná, Ivinhema até o sul do rio Iguatemi 16 .

O total das posses registradas em nome de Antonina foi calculado em cerca 90.000 quilômetros quadrados ${ }^{17}$, referindo-se aos registros delas, Virgílio Corrêa Filho afirma:

Obtidos, porém, aqueles documentos, na sua generalidade invalidados por defeitos vários, ter-se-ia dado pressa o Barão de Antonina, contemporaneamente à decretação da Lei de Terras $\mathrm{n}^{\circ}$ 601 , de 20 de setembro de 1850 , cuja elaboração, no Parlamento, não era, desde muito antes, ignorada das pessoas em destaque na política do Império, - em pagar, na coletoria de Miranda, o imposto de siza, visando certamente pôr os instrumentos literais daquele negócio de acôrdo com as exigências estabelecidas posteriormente no Regulamento daquela Lei, publicado em 1854. Além, toda via, da enunciação de limites confusos ou topograficamente inexistentes. As pessoas que, naqueles curiosos documentos

\footnotetext{
${ }^{15}$ A proposta enviada ao imperador foi fruto de investigações levadas pelo barão a respeito das reduções jesuíticas guarani, incluindo a antiga cidade de Santiago de Xerez. Porém, o novo projeto de civilização submetia-se às ordens do império e ao trabalho dos frades Capuchinhos (WISSENBACH, 1995, p. $144 \mathrm{e}$ 149). A relação de Antonina com os povos de língua guarani parece ter início em 1830, quando os Oguauíva, oriundos da região do rio Iguatemi (MS) se deslocaram em direção ao Paraná e se instalaram em uma de suas fazendas (NIMUENDAJU, 1987, p. 08-12). Amoroso também registrou a presença dos Apapokuva mencionados por Nimuendaju no Aldeamento de São Pedro de Alcântara, associado à Colônia Militar do Jataí, na década de 1860 (NIMUENDAJU, 1987, p. 139), localizados às margens do rio Tibagi, afluente do Paranapanema.

${ }^{16}$ Veja: Lopes et al (2007), Elliot (1848, p. 173; 1856, p. 434, apud MONTEIRO, 2003, p. 17) e Lopes, 1850, p. 320-321, apud MONTEIRO, 2003, p. 23-24). Os dados kaiowa e o material produzido por Nimuendaju (1987, p. 05) ratificam os registros destes exploradores.

${ }^{17}$ Ver: Penço (1980, apud AMOROSO, 1998, p. 52) e Wissenbach (1995, p. 138).
}

Espaço Ameríndio, Porto Alegre, v. 7, n. 2, p. 26-63, jul./dez. 2013. 
KATYA VIETTA - Histórias territoriais...

figuraram como vendedoras de terras extensas incluíram até regiões inteiras dominadas, naquela época, exclusivamente por indígenas bravios, e por onde não seria fácil transitar impunemente homem civilizado, o que concorre para evidenciar a natureza de simulação fantástica por que se definia todo esse negócio... (CORRÊA FILHO, 1945, p. 152-153).

Ao finalizar a análise dos registros de viagem de Lopes e Elliot, Almeida (2010, p. 45-46) 18 conclui:

Os devassadores penetravam nos sertões bravios, descortinavam trechos territoriais desde logo delimitados por acidentes visíveis: a foz ou a correte de um córrego, de um ribeiro ou de um rio; uma protuberância de terra; a vizinhança de uma serra; a existência de uma árvore de maior porte; a particularidade de determinada qualidade de vegetação local. E a olho a posse ficava demarcada pela ocorrência de tais acidentes.

Habitualmente, os devassadores assinalavam também a existência da posse e procediam à sua demarcação mediante fixação, no solo, de estacas, obtidas no próprio local da gleba. A posse a que se referiam os devassadores, não era nenhuma relação jurídica, enquadrada nas doutrinas específicas conhecidas. Restringia-se ao corpus. A posse era a própria gleba. E o respectivo agente tinha tantas posses quantas fossem as unidades de glebas dela componentes. Em última análise, a formação de tais posses, nesse regime, como fato jusrísgeno de propriedade territorial, equiparava-se ao descobrimento de terras ampliadoras do domínio eminente das nações, aplicado à aquisição de domínio patrimonial privativo, consideradas as terras descobertas como res nullius...

As terras nesse regime de 'descobrimento', aparentemente não teriam dono. Seriam na interpretação dos desbravadores, res nullious, apropriáveis pelo que primeiro descortinasse as glebas, demarcando-as de soslaio para a realização de negócios de compra e venda, por preços insignificantes que toda via remuneravam o trabalho arriscado dos 'descobrimentos'. Foi por esse processo que se constituíram e fundaram dezenas de fazendas

\footnotetext{
${ }^{18}$ Almeida era advogado e na década de 1920 atuou como consultor jurídico do governo de Mato Grosso. Parte do conteúdo publicado na obra em questão tem por base as pesquisas realizadas para a instrução de processos fundiários envolvendo interesses daquele governo, incluindo o processo movido pelos herdeiros do barão de Antonina visando à regularização de posses em nome deste.
}

Espaço Ameríndio, Porto Alegre, v. 7, n. 2, p. 26-63, jul./dez. 2013. 
KATYA VIETTA - Histórias territoriais...

agrícolas, em especial no planalto de Amambaí (ALMEIDA, 2010, p. 45-46).

Os herdeiros de Antonina buscaram regularizar tais posses que abrangiam parte considerável das terras habitadas pelos Kaiowa e Guarani (Ñandeva). Conforme Rodrigues, estas se localizavam às margens dos rios Dourados, Apa, Miranda, Amambai, Iguatemi, Cruzes, Pedra de Cal, Santa Maria e São Domingos, na época uma "região selvagem", habitada apenas por índios (ALMEIDA, 2010, p. 100)19. Em 1931 o pleito dos herdeiros de Antonina foi definitivamente negado sob a alegação de que as posses não eram habitadas por eles. Procedimento divergente ao obtido pelas famílias Lopes, Gonçalves e muitas outras, que lograram êxito na regularização de suas imensas posses.

Entre as regras para a regularização das sesmarias e outras posses definidas pela Lei de Terras, editada 1850 e regulamentada 1854 pelo decreto 1.318 , estão: a criação do registro de terras possuídas; a fixação de regras para a revalidação de sesmarias e legitimação de posses, exigindo a comprovação de ocupação através do cultivo e da habitação; proibição da formação de novas posses; a definição da apropriação de terras mediante compra; a distinção entre as noções de terra indígena e terra devoluta ${ }^{20}$. A aplicação da Lei de Terras foi atribuída aos governos provinciais. No Mato Grosso a Repartição de Terras, criada no final dos anos 1850, não foi capaz de coibir novos apossamentos ou diminuir os conflitos e a violência no trato da questão fundiária21. Situação vinculada à ausência de clareza quanto à comprovação de ocupação e ao fato de a delimitação e demarcação das terras ficar ao cargo de seus ocupantes. A passagem das terras devolutas ao domínio das províncias acirrou este quadro,

\footnotetext{
${ }^{19}$ A respeito das posses adquiridas por Antonina em terras sul-mato-grossenses e do processo judicial pleiteando a sua regulamentação, Ver: Lopes (2007), Almeida (2010, p.29-85), Guimarães (1992, p.32; 1999, p.91), Rosa (2004, p.34-36), Rodrigues (1984 p. 99-102), Saboya (1995, p 129-132) e Wissenbach (1995, p.138). A única posse em nome do barão tida como legítima foi a fazenda Sete Voltas (Maracaju), que estava sob os cuidados de seu filho, Pedro Nolasco. Em 1875 ela foi vendida a Thomaz Laranjeira, Veja: (RODRIGUES, 1984, p. 102; ROSA, 2004, p. 35; GUIMARÃES, 1992, p. 40). Aliás, parte significativa das posses do Barão de Antonina foi adquirida por Thomaz Larangeira e sua empresa ervateira ou figurou entre as terras sob seu monopólio, como mostro a seguir.

${ }^{20}$ Ver: Saboya (1995, p. 122), Osório Silva (1999, p. 02-03), Targa Moreira (1990, p. 158-159 e 167), Pacheco (2004, p. 51-55 e 70), Carneiro da Cunha (1987, p. 66-67) e Azanha (2001, p. 02-03).

${ }^{21}$ Ver: Esselin (2003, p. 170) e Salsa Corrêa (1999, p. 166).
}

Espaço Ameríndio, Porto Alegre, v. 7, n. 2, p. 26-63, jul./dez. 2013. 
KATYA VIETTA - Histórias territoriais...

pois a relação entre latifúndio e oligarquia orientava o trato da questão fundiária22.

Reafirmando os dispositivos legais gerados no período colonial, o decreto 1.318 determinou a reserva das terras para as populações indígenas e definiu os procedimentos para tanto:

Capitulo VI - Das terras reservadas

Art. 72. Serão reservadas terras devolutas para colonisação e aldeamento de indígenas nos districtos onde existirem hordas selvagens.

Art. 73. Os Inspectores e Agrimensores, tendo noticia da existencia de taes hordas nas terras devolutas que tiverem de medir, procurarão instruir-se de seu genio e índole, do numero provavel de almas que ellas contêm, e da facilidade ou dificuldade que houver para o seu aldeamento, de tudo informarão ao Director geral das terras publicas por intermedio dos Delegados indicando - lugar o mais azado para o estabelecimento do aldeamento, e os meios de o obter; bem como a extensão da terra para isso necessaria.

Art. 74. A vista de taes informações, o Director geral proporá ao Governo Imperial a reserva das terras necessarias para o aldeamento, e todas as providencias para que este se obtenha.

Art. 75. As terras reservadas para colonisação de indígenas, e por elles distribuídas, são destinadas ao seu usufructo; e não poderão ser alienadas emquanto o Governo Imperial por acto especial não Ihes conceder o pleno gôzo dellas, por assim o permittir o seu estado de civilisação.

Art. 76. Os mesmos Inspectores e Agrimensores darão noticia, pelo mesmo intermedio, dos lugares, apropriados para a fundação de povoações, abertura de estradas, quaesquer outras servidões, bem como para assento de estabelecimentos publicos; e o Director geral das terras publicas proporá ao Governo Imperial as reservas que julgar convenientes.

Art. 77. As terras reservadas para fundação das povoações serão divididas, conforme o Governo julgar conveniente em lotes urbanos e ruraes, ou sómente nos primeiros. Estes não serão maiores de 10 braças de frente e 50 de fundo. Os ruraes poderão ter maior extensão, segundo as circumstancias o exigirem, não ex-cedendo porém cada lote de 400 braças de frente

${ }^{22}$ Ver: Saboya (1995, p. 122), Osório Silva (1999, p. 02-03) e Targa Moreira (1990, p. 158-159).

Espaço Ameríndio, Porto Alegre, v. 7, n. 2, p. 26-63, jul./dez. 2013. 
KATYA VIETTA - Histórias territoriais...

sobre outras tantas do fundo (FREITAS JR., 1882, p. $107-110)^{23}$.

Entretanto, não há qualquer registro no sentido de salvaguardar aos povos indígenas sul-mato-grossenses o direito sobre as terras por eles habitadas, seja atendendo à legislação colonial seja atendendo à Lei de Terras, e pouco se garantiu depois disso. Apesar da imponente missão autoproclamada pela Comissão de Linhas Telegráficas e pelo Serviço de Proteção aos Índios (SPI), em terras sul-mato-grossenses, o que eles mais fizeram foi sedimentar a desleixada confusão entre terras devolutas e terras indígenas, permanentemente atualizada desde a proclamação da Lei de Terras.

A guerra com o Paraguai mostrou ao governo brasileiro a necessidade de investir mais no incremento do povoamento, na geração de alternativas econômicas e na agilização da comunicação com a região de fronteira. Para isso deu início a pesados investimentos voltados para a construção de ferrovias, desenvolvimento da navegação fluvial e implantação de comunicação telegráfica. Comandada pelo marechal Cândido Mariano da Silva Rondon, a Comissão Construtora de Linhas Telegráficas de Mato Grosso (1900-1930)24 foi responsável por estender a linha ao longo da fronteira com o Paraguai e a Bolívia e mais ao norte, além de construir estradas e pontes ligando as estações. Idealizada e conduzida por oficiais do exército, a Comissão representava uma estratégia militar, política, científica e tecnológica para a conquista dos sertões (MACIEL, 1999, p. 168-178) e para a guarnição da fronteira internacional. Para ampliar tais pretensões em 1910 foi criado o Serviço de Proteção aos Índios e Localização de Trabalhadores Nacionais (SPILTN), igualmente comandado por Rondon, com a função de localizar e assistir índios e trabalhadores rurais ${ }^{25}$. Mas o trato da questão indígena, tanto pelo SPI como pela Comissão,

\footnotetext{
${ }^{23}$ Ver também Azanha (2001, p. 2).

${ }^{24}$ A Instalação da comunicação telegráfica foi um projeto gestado no governo imperial, que em 1888 enviou à província do Mato Grosso uma força militar e uma equipe de engenheiros, para dar início aos procedimentos necessários para instalar a Rede Telegráfica Nacional, mas os trabalhos foram suspensos com o fim do império (GAGLIARDI, 1989, p.137).

${ }^{25}$ O Serviço de Proteção aos Índios e Localização de Trabalhadores Nacionais (SPILTN), criado em 1910, passou à história como SPI a partir de 1918.
}

Espaço Ameríndio, Porto Alegre, v. 7, n. 2, p. 26-63, jul./dez. 2013. 
KATYA VIETTA - Histórias territoriais...

também envolvia a desintrusão de parte das terras indígenas para a instalação de projetos de colonização 26 .

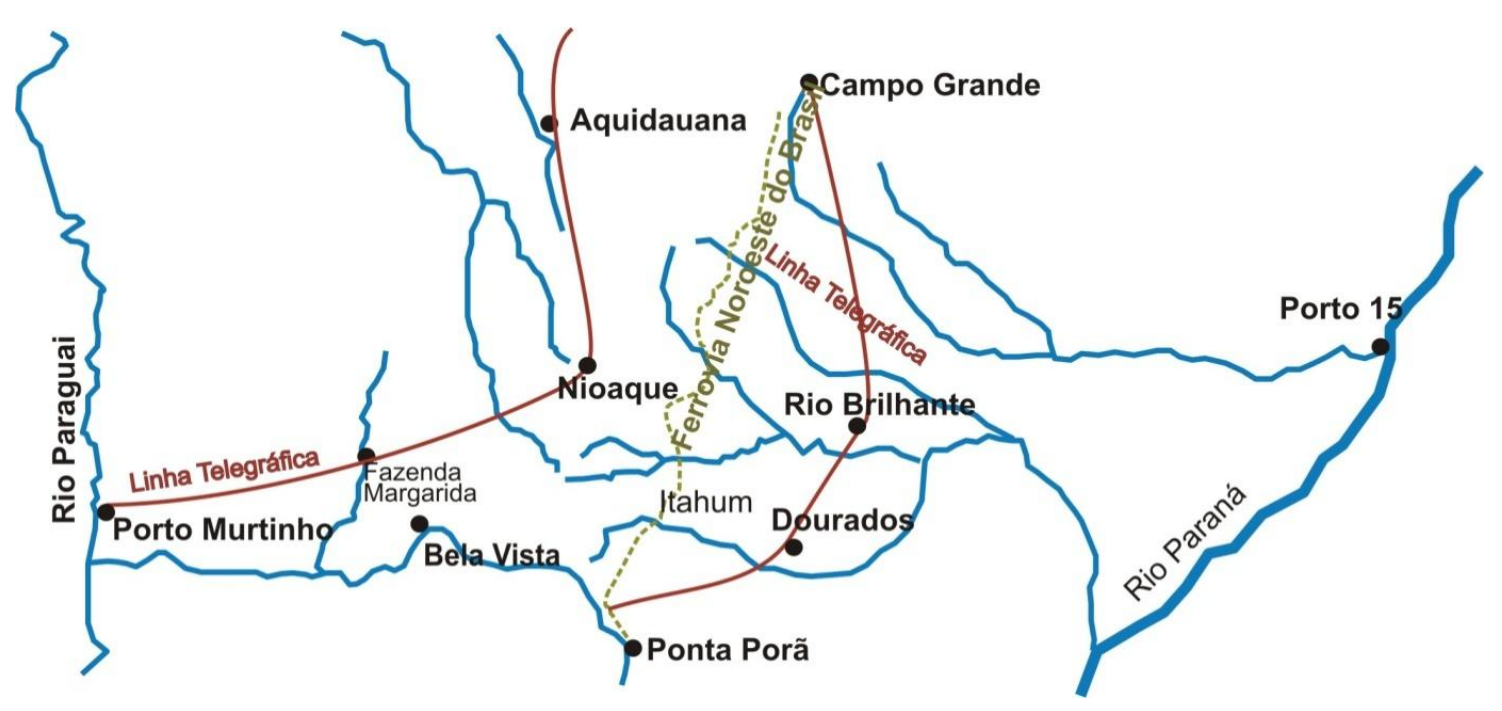

Fonte: Guimarães 1999, mapa encarte terena.

Em território sul-mato-grossense, a atuação da Comissão se deu entre 1904-1927, passando por terras terena, kaiowa e guarani (ñandeva), mas sem a retumbante atuação observada junto às populações indígenas localizadas mais ao norte. Aos Terena coube, em 1905, as demarcações dos Postos Indígenas (PIs) Cachoeirinha e Bananal/ Ipegue - ambos regularizadas em 1911, mas com litígios que se arrastam até o presente - e mais cinco pequenos Pls criados entre 1910 e 1920. Para os Kaiowa e Guarani, entre 1915 e 1928 foram delimitados sete PIs, inicialmente com 3.600 hectares cada, a fim de concentrar uma imensa população dispersa na região sul do estado. São eles as atuais Reservas de: Dourados (Dourados), Caarapó (Caarapó), Sassoró (Ponta Porã), Pirajuy (Sete Quedas), Takuapery (Coronel Sapucaia), Amambai (Amambai) e Porto Lindo (Porto Lindo). Porém as dificuldades para as suas regularizações foram tantas que ao final da década de 1960 ainda havia pendências para quatro delas, e todas já haviam enfrentado algum tipo de redução em sua área. Como compensação às perdas territoriais do PI Benjamim Constant (Reserva de

\footnotetext{
${ }^{26}$ Ver: Lima (1995, p. 178) e Arruda (2005, p. 2-4).
}

Espaço Ameríndio, Porto Alegre, v. 7, n. 2, p. 26-63, jul./dez. 2013. 
KATYA VIETTA - Histórias territoriais...

Amambai), foi demarcado o PI Poblito (Reserva de Limão Verde, Amambai), que perdeu um terço das terras antes da sua regularização ${ }^{27}$. Acrescente-se a este quadro a promessa, não cumprida, feita aos Kaiowa, da demarcação de Ka'aguirusu, mais de 50.000 hectares localizados à margem direita do rio Brilhante, como parte das negociações para a utilização das terras e da mão de obra destes índios durante os trabalhos da Comissão de Linhas Telegráficas entre 1919 e $1927^{28}$.

A ausência de uma política indigenista voltada, de fato, para o atendimento do conjunto desta população e a crescente redução de suas terras, restringindo cada vez mais a produção econômica familiar, levou um grande número de famílias indígenas para o interior de fazendas ou acampamentos ervateiros, trocando moradia por trabalho árduo ou pela escravidão por dívida. O exemplo da Cia Matte Larangeira é o mais emblemático na geração desta e de outras transgressões no trato da questão indígena.

Até a guerra, o Paraguai dominou o mercado ervateiro, mas a nova fronteira deixou em terras brasileiras boa parte dos ervais nativos ${ }^{29}$. Tendo à frente Rufino Enéas Galvão e Antonio Maria Coelho, a Comissão de Limites, responsável pela demarcação da nova fronteira internacional, atuou entre 1872 e 1874. Thomaz Larangeira foi um de seus provisionadores ${ }^{30}$. A partir do apossamento de terras entre o rio Dourados e o arroio Estrela, Larangeira se inseriu na exploração ervateira ${ }^{31}$.

Em 1882, Enéas Galvão, então presidente da província, intermediou a concessão imperial para Larangeira explorar ervais em

\footnotetext{
${ }^{27}$ Ver: Monteiro (2003, p. 39-40 e 151-157) e Vietta (2007, p. 73-79).

${ }^{28}$ Embora não haja qualquer registro escrito a este respeito, a passagem da Comissão entre os Kaiowa, a utilização de sua mão de obra e a delimitação de Ka'aguirusu são temas de domínio público entre os Kaiowa que habitam as terras banhadas pelos rios Brilhante, Dourados e afluentes - Ver: Vietta (2007, p. 80-95 e 2012c). Aliás, são raros os relatórios ou análises a respeito dos trabalhos da Comissão que fazem referência a sua estada entre os Kaiowa por quase uma década.

${ }^{29}$ Bianchini (2000, p. 87) e Arruda (1986, p. 211).

${ }^{30}$ Para abastecer a Comissão de Limites, foi contratada uma casa de comércio de Porto Alegre (RS), que escalou Thomaz Larangeira e Ernesto Paiva para o trabalho (GRESSLER e SWENSSON, 1988, p. 28).

${ }^{31}$ Ver: Corrêa (1985, p.71; 1999, p. 40), Corrêa Filho (1939, apud PACHECO, 2004, p. 31), Guimarães (1992, p. 46), Rosa (2004, p. 20) e Arruda (1989, p.207). A respeito da biografia de Thomaz Larangeira e da Comissão de Limites, ver: Arruda (1989, p.38), Corrêa (1999, p.40), Gressler e Swensson (1988, p. 28), Rodrigues (1984, p. 119), Guimarães (1999, p. 211 e 217) e Rosa (2004, p. 18-19).
}

Espaço Ameríndio, Porto Alegre, v. 7, n. 2, p. 26-63, jul./dez. 2013. 
KATYA VIETTA - Histórias territoriais...

terras tidas devolutas por 10 anos $^{32}$, permitindo a criação da Cia Matte Larangeira. A república conduziu Maria Coelho à presidência do Mato Grosso, quem garantiu àquele a ampliação do arrendamento por mais 10 anos, em regime de monopólio (ARRUDA, 1986, p. 39-40 e 212). Em 1991, Larangeira contraiu empréstimo junto ao Banco Rio-Mato Grosso, presidido por Joaquim Murtinho. Em 1892, o irmão deste - Manoel José Murtinho - foi nomeado presidente do estado. No mesmo ano o banco comprou $97 \%$ das ações da Cia Matte 33 e venceu a concorrência para explorar os "terrenos devolutos" ao sul do rio Iguatemi34. Os arrendamentos foram ampliados em 1894 e em 189535, atingindo 5.000.000 hectares. A renda obtida pela Matte Larangeira em diversos anos superou cerca de seis vezes o orçamento total do estado36.

O monopólio inviabilizou a concorrência legal, mas não impediu o contrabando da erva. Nos arrendamentos, quem não trabalhava para a Cia era perseguido pelas milícias do estado e pelos comitiveiros milícia criada pela empresa para deter e punir com castigos físicos e com a morte quem desafiasse o seu poder, incluindo os trabalhadores que buscavam na fuga a liberação da escravidão por dívida 37 e os novos colonos que queriam ocupar as terras monopolizadas pela empresa. Em

\footnotetext{
${ }^{32}$ Decreto 8.799, de 09 de dezembro de 1882 (apud, ARRUDA, 1989, p. 276).

${ }^{33}$ Sobre o contexto político das disputas pela presidência do Mato Grosso, ver: Corrêa (1995, p. 67-69 e 82-88; 1999, p. 52-56), Queiroz (2004, p. 135-137) e Arruda (1986, p. 39-41). Para a associação da Cia Matte com o Banco Rio-Mato Grosso e com a família Murtinho, ver: Corrêa (1999, p. 62-63), Arruda (1989, p. 40-43; 1986, p. 215-217 e 234-237) e Bianchini (2000, p. 88-90).

${ }^{34}$ Nesta concorrência foi disponibilizada a exploração de erva-mate e de outros produtos vegetais (Lei 26.11.1892, apud ARRUDA, 1986, p. 217).

${ }^{35}$ Resolução 76, de 13.07.1894 e Resolução 102 de 15.07.1895, respectivamente (apud ARRUDA, 1989, p. 42-43).

${ }_{36}$ Arruda (1989, p. 40-43; 1986, p. 200-218), Corrêa (1999, p. 88) e Queiroz (1997, p. 119).

${ }^{37}$ Arruda $(1989$, p. 39-43, 50-51, 159-165). Entre as formas de atrair os trabalhadores estão: o conchavo e o antecipo. Associado ao comissário de polícia local, o conchavador promovia um baile farto em cachaça, quando descrevia aos convidados as vantagens dos trabalhos nos ervais e lhes oferecia um adiantamento ou antecipo (PUIGGARI, 1933, p. 25, apud ARRUDA, 1989, p. 150-151). Ver também: Bianchini (2000, p. 172-175). O antecipo era concedido antes de uma festa oferecida aos trabalhadores que aguardavam o barco para levá-los aos ervais. Este, propositadamente, demorava três dias, período em que o dinheiro era gasto com bebidas, mulheres e outras extravagâncias, garantindo ao trabalhador uma enorme dívida (WACHOWICZ, 1982, p. 54-55, apud LENHARO, 1986, p. 63). Entre os expedientes usados para garantir a dívida ainda estava: alterar a balança de pesagem da erva; promover bailes no interior dos acampamentos, onde eram oferecidas cachaça e mulheres (LENHARO, 1986, p. 154-156). Não raro um trabalhador entregava a mulher ou filha(s) para outros trabalhadores, a fim de transferir ou amenizar a sua dívida. Lenharo ainda menciona a exploração das filhas dos trabalhadores através da prostituição precoce (LENHARO, 1986, p. 63). Corrêa (1985, p. 150) menciona o sequestro como uma das formas de aliciamento de trabalhadores.
}

Espaço Ameríndio, Porto Alegre, v. 7, n. 2, p. 26-63, jul./dez. 2013. 
1915 a oposição política à Cia Matte ${ }^{38}$ garantiu a publicação da resolução estadual 725 , trazendo regras para a regularização de posses $^{39}$ e fixando novos limites para os arrendamentos, mais uma vez burlados pela companhia, o que se repetiu em 192640 .

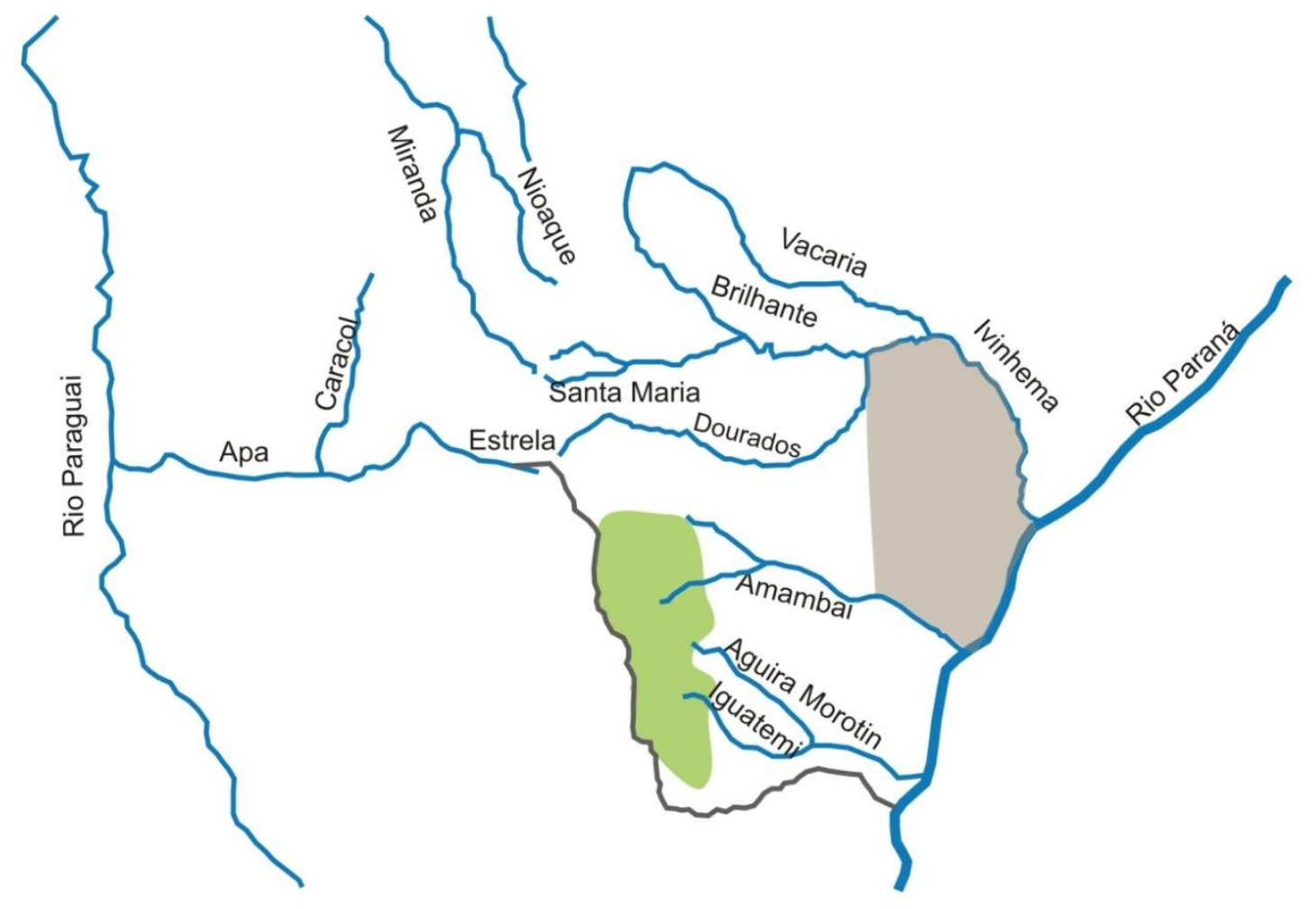

Área Concedida a Thomaz Larangeira - Decreto 8.799 - 1882

Área Concedida à Cia Matte Larangeira - Lei 520 - 1890

Figura 03: Terras concedidas à Cia Matte Larangeira 1882- 1890

Fonte: Arruda, 1986, p. 214

\footnotetext{
${ }^{38} \mathrm{~A}$ respeito da oposição frente à presença de empresas estrangeiras na faixa de fronteira, ver: Queiroz (2004, p.135-137) e Arruda (1989, p. 51-54).

${ }^{39}$ A resolução estadual 725 , de 24.09.1915 permitiu a regularização de dois lotes, de 3.600 hectares cada, para aqueles ocupantes de terras de lavoura e pastagens, desde que comprovada cultura efetiva e moradia anterior a 1914. Apesar de a Matte contestar, com êxito, uma parte considerável das requisições dos posseiros, até 1924 foram expedidos 356 títulos provisórios de propriedade no então município de Ponta Porã, totalizando 620.702 hectares (CORRÊA FILHO, 1925, p. 91, apud ARRUDA, 1989, p. 73). Ver também: Arruda (1989, p.54-56 e 69-72), Corrêa (1999, p.68), Bianchini (2000, p.102 e 106) e Guillen (1999, p. 152). A resolução 725 parece ter sido um dos primeiros procedimentos voltados para a regularização das terras localizadas ao longo da fronteira com o Paraguai, permitindo que seus ocupantes saíssem da condição de posseiros.

${ }^{40}$ Ver: Arruda (1986, p. 218-219; 1989, p. 74) e Bianchini (2000, p.102 e 111). Além da área arrendada, a empresa era proprietária de mais de 300.000 hectares (GUILLEN, 1999, p. 159).
}

Espaço Ameríndio, Porto Alegre, v. 7, n. 2, p. 26-63, jul./dez. 2013. 


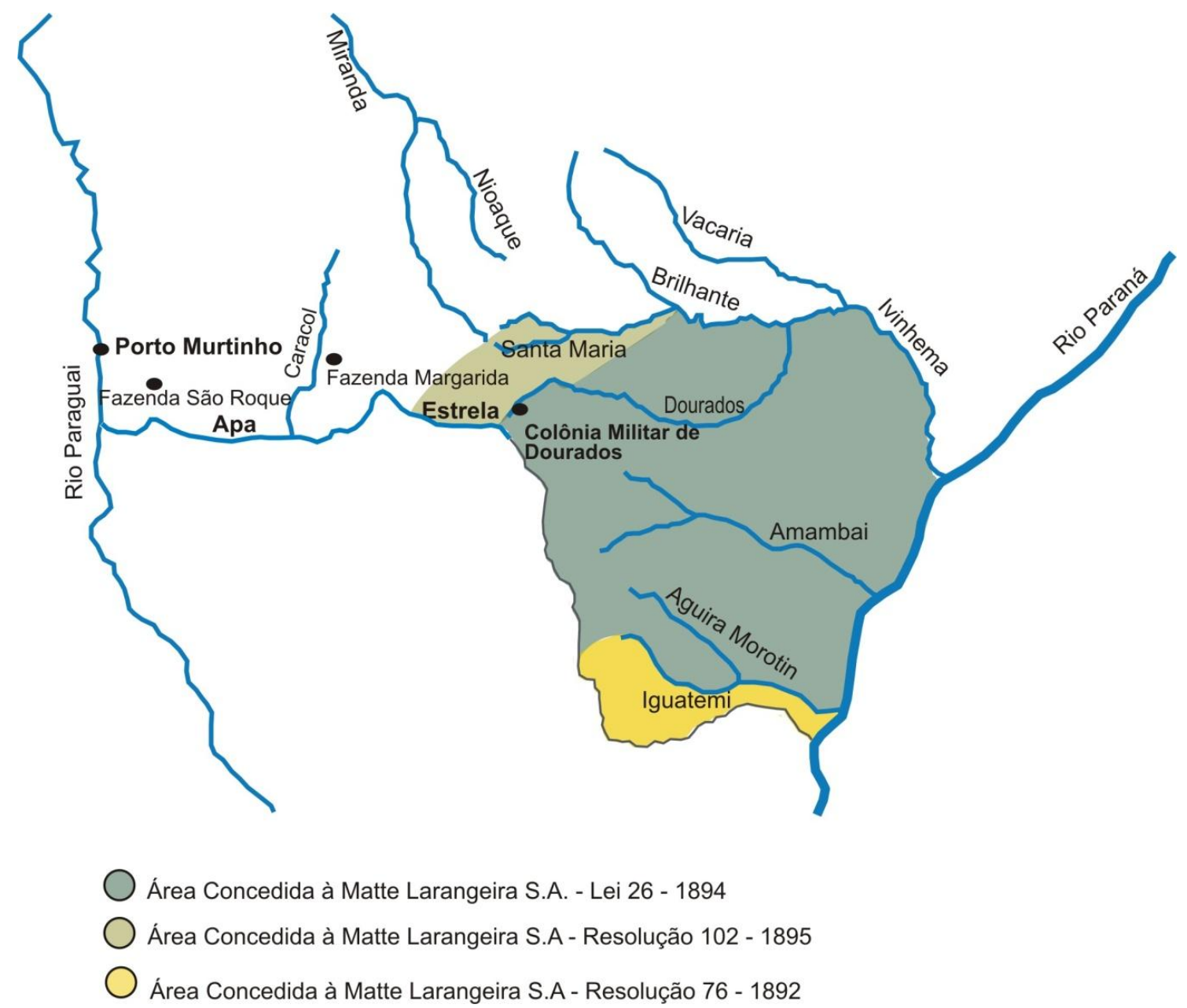

Figura 04: Terras concedidas à Cia Matte Larangeira 1892- 1895 Fonte: Arruda (1986, p. 220-222); Guimarães 1999, mapa encarte.

As novas restrições, associadas ao barateamento do escoamento pelas vias fluviais, levou a empresa a estender a sua atuação ao estado do Paraná, através dos rios Brilhante, Ivinhema e Paraná, ainda na década de 191041, onde também angariou muitos privilégios. (LENHARO, 1986, p. 66; BIANCHINI, 2000, p. 138-150). Porém, a década de 1930 marcou o declínio da Cia Matte. Com o domínio da tecnologia de plantio da erva, a Argentina, seu maior mercado consumidor, tornou-se autossuficiente. Getúlio Vargas sustentou uma política de oposição à empresa e às oligarquias opositoras ao seu governo a ela associadas. Figuraram entre as ações de seu governo:

${ }^{41}$ Veja decreto 232, de 01 de setembro de 1909 (apud ARRUDA, 1986, p.239).

Espaço Ameríndio, Porto Alegre, v. 7, n. 2, p. 26-63, jul./dez. 2013. 
KATYA VIETTA - Histórias territoriais...

simplificação da legislação para a aquisição de terras no sul de Mato Grosso (BIANCHINI, 2000, p. 163); criação do Instituto do Matte42; sobretaxação da exportação da erva cancheada ${ }^{43}$ e incentivo à produção industrializada (LENHARO, 1986, p. 66); criação da Lei de Nacionalização do Trabalho, obrigando as empresas exploradoras de concessões públicas a ter pelo menos dois terços de funcionários brasileiros entre os contratados, fazendo Larangeira substituir parcela considerável de seus trabalhadores ditos paraguaios ${ }^{44}$. Em 1944 a Cia Matte foi transformada em Autarquia Federal Serviço de Navegação da Bacia do Prata (BIANCHINI, 2000, p. 244), quando suas terras integravam os Territórios Federais de Ponta Porã (incidindo sobre grande parte do atual Mato Grosso do Sul) e de Iguaçu (incidindo sobre o oeste do Paraná), criados por Vargas para ampliar seu controle local45.

Ao contrário do que consta nos registros da Matte, parte significativa de seus ervateiros era recrutada entre os Kaiowa e os Guarani46. Monteiro (2003, p. 31 e 67-107) apresenta dados colhidos em avisos de PIs e relatórios produzidos pelo SPI no início de século XX, registrando que a empresa detinha o arrendamento de terras indígenas e se utilizava da mão de obra de seus habitantes em "regime de escravidão"47, a qual muitas vezes era agenciada através dos próprios

\footnotetext{
${ }^{42}$ Com a incumbência realizar pesquisas e conquistar mercado, como forma de fortalecer os produtores que atuavam fora da esfera da Cia Matte. Em 1938, órgão foi é federalizado e designado Instituto Nacional do Mate (BIANCHINI, 2000, p. 62).

${ }^{43}$ No Mato Grosso, a Cia Matte fazia apenas a secagem da erva, comercializando a folha in natura, com isso favorecendo outros produtores.

${ }^{44}$ Bianchini (2000, p. 176-177) e Arruda (1989, p. 22-23).

${ }^{45}$ Os territórios federais de Ponta Porã e de Iguaçu foram criados em 1943, mediante o argumento de que as terras na faixa de fronteira estavam em mãos de companhias estrangeiras - e no estado do Mato Grosso a Matte não era a única -, colocando em risco a segurança nacional ao coibir o seu povoamento (LENHARO, 1986, p. 66). Não por coincidência, a demarcação dos novos centros administrativos incidiu sobre as terras ervateiras exploradas pela Matte. Na ocasião Vargas também criou os territórios federais de Guaporé, Amapá e Rio Branco.

${ }^{46} \mathrm{Na}$ virada do século XX, o sul da província do Mato Grosso abrigava uma escassa população não indígena, contribuindo para que historiadores confiassem que a Cia Matte se utilizasse de trabalhadores paraguaios. Para Bianchini, fato atestado pela preocupação frente à Lei de Nacionalização do Trabalho, explicitada em sua correspondência interna (2000, p.175-176). Em geral, tal argumento se atrela à disponibilidade desta mão de obra no contexto das sucessivas crises que assolaram o Paraguai após a guerra (CORRÊA, 1999, p. 40-41; SALSA CORRÊA, 1999, p. 118 e 202; BIANCHINI, 2000, p. 192; ESSELIN, 2003, p. 238-239). Mas, de acordo com Doratioto (2002, p. 456), esta vitimou 99\% da população masculina paraguaia, portanto é preciso repensar o argumento (TSCHIKEL, 2005). Por outro lado, ao definir seus trabalhadores como paraguaios, Larangeira descaracteriza o uso das terras e da mão de obra indígena.

${ }^{47}$ Veja Relatório do auxiliar Genesio Pimental Barbosa referente ao ano de 1927, encaminhado para Antonio Martins Viana Estigarribia - Diretor da $5^{\mathrm{a}}$ Inspetoria Regional (IR5) - SPI, Campo Grande,
}

Espaço Ameríndio, Porto Alegre, v. 7, n. 2, p. 26-63, jul./dez. 2013. 
KATYA VIETTA - Histórias territoriais...

Pls; bem como o número de trabalhadores kaiowa e guarani nos ranchos da companhia era muito superior ao de paraguaios. Portanto, durante 70 anos a empresa fundada por Thomaz Larangeira exerceu 0 controle das terras ervateiras e da população que nela habitava ou pretendia habitar. Controle calcado no fiel apoio da família Murtinho, que se consolidou política e financeiramente através da Cia Matte Larangeira. Porém as terras arrendadas não eram devolutas, como consta nos contratos, mas terras habitadas pelos Kaiowa e pelos Guarani. No entanto, o fechamento da empresa não significou o fim deste tipo de apropriação irregular, que também foi sustentada pelo governo Vargas.

A Constituição republicana (1891) não mencionou os índios, o que para muitos juristas não suplantou o instituto do indigenato48. De qualquer forma as ações levadas a cabo pelo governo do Mato Grosso, Cia Matte Larangeira e pelo governo federal transgrediram: O decreto federal 5.484 , de 1928, que fixou a cessão das terras do Patrimônio Nacional necessárias para implantação dos PIs administrados pelo SPI, incluindo as "terras devolutas, pertencentes aos Estados, que se acharem ocupadas pelos índios"; O decreto federal, de abril de 1936, que incumbiu o SPI de "impedir que as terras habitadas pelos silvícolas fossem tratadas como se devolutas fossem"; As Constituições de 1934 e 1937, que determinaram o respeito à posse indígena das terras habitadas por eles, vetando a sua alienação. Em 1943, ao criar a Colônia Nacional de Dourados - CAND ${ }^{49}$, Vargas também criou precedente para que a Constituição de 1946 fosse ferida. Esta manteve as determinações das Cartas anteriores e impediu a transferência dos índios de suas terras ${ }^{50}$.

No início dos anos 1940, Vargas criou 12 Colônias Agrícolas Nacionais vislumbradas como polos de produção rural, capazes de em

14.12.1927 (apud MONTEIRO, 2003, p. 67-107). Qualquer Kaiowa tem alguma história para contar a respeito do tempo dos trabalhos nos ervais.

${ }^{48}$ Bandeira e Miranda (1947, apud CARNEIRO DA CUNHA, 1987, p. 67).

${ }^{49}$ O decreto 5.941 de 28.10.1943, que criou a CAND, foi assinado depois da criação do território federal de Ponta Porã; portanto, teve a instalação prevista em terras da União. Com a extinção deste território (1946), a área reservada foi mantida pelo estado de Mato Grosso (lei 87, de 20.07.1948), nos mesmos termos do decreto federal. Porém, a lei 87 sofreu alterações em 1948 e em 1949 (GRESSLER e SWENSSON, 1988, p. 89-93).

${ }^{50}$ Veja: Carneiro da Cunha (1987, p. 76) e Lima (1995, p.214).

Espaço Ameríndio, Porto Alegre, v. 7, n. 2, p. 26-63, jul./dez. 2013. 
KATYA VIETTA - Histórias territoriais...

10 anos tornarem-se centros urbanos e microindustriais ${ }^{51}$; mas apenas a CAND alcançou êxito, atraindo muito apoio federal (LENHARO, 1986, p. 46-49 e 55-57). Dos 409.000 hectares destinados a ela, 130.000 foram alvo de negociações ilícitas. Mesmo assim, a partir da CAND fundaram-se as bases para o surgimento dos municípios de Dourados, Douradina, Fátima do Sul, Jateí, Glória de Dourados e Deodápolis. Também incentivados por Vargas, outros projetos públicos e privados de colonização deram origem aos municípios de Itaporã, Bataiporã, Anaurilândia, Bataguaçu, Nova Andradina, Ivinhema e Naviraí (GLESSLER; SWENSSON, 1988, p. 33 e 82-95). Todos se utilizando de terras indígenas, na maioria kaiowa.

Parte da CAND se sobrepôs a Ka'aguirusu, como já dito, terras kaiowa delimitadas no contexto dos trabalhos da Comissão, mas não demarcadas pelo SPI. Após meses de negociações, alguma corrupção, violência contra os índios e alterações funcionais ${ }^{52}$, Joaquim Fausto

\footnotetext{
${ }^{51}$ Entre 1941-1944, Vargas também criou as Colônias Agrícolas Nacionais de Goiânia (GO), Bela Vista (AM), Monte Alegre (PA), Barra do Corda (MA), General Osório (PR), Oeiras (PI) (BEZERRA, 1994, p. 77).

52 De acordo com os Kaiowa, a primeira solução vislumbrada pela CAND foi transferi-los para o PI Francisco Horta, mas estes, liderados por Pedro Henrique, apoiados por Acácio Arruda - agente do PI - e por Nicolau Bueno Horta Barbosa - chefe da IR5 -, passaram a reclamar seus direitos. Após nove meses de negociações, sem qualquer êxito, Ka'aguirusu foi invadido pela polícia indígena daquele PI, sob o comando de Acácio Arruda. Por este feito, tanto a polícia indígena quanto Arruda receberam favores do diretor da CAND. Habitantes de Ka'aguirusu foram coagidos, agredidos, presos e encaminhados ao PI. A intervenção de Horta Barbosa, favorável a estes, lhe garantiu o afastamento da chefia da IR5, que passou para Fausto Prado; enquanto em Dourados, Fioravante assumiu a frente do PI. Pedro Henrique, por diversas vezes, foi preso e afastado de Ka'agurusu (VIETTA, 2007, p. 104-111). Existe farta documentação dando conta do expediente interno do SPI e da comunicação deste com a CAND, anexadas a diferentes processos fundiários envolvendo as terras apropriadas pela CAND. Esta documentação foi analisada em Vietta (2007, p. 96-130). Veja também Vietta (2011 e 2013), onde tais análises foram ampliadas e aprofundadas. Para os dados aqui apresentados, ver: Telegrama de Acácio Arruda, agente do PI Francisco Horta (26.7.1946), enviado a Nicolau Horta Barbosa, chefe da IR5, Campo Grande (MI/CDMI/ F.17/p.247 apud BEZERRA, 1994, p. 105-106); Of. 96, assinado por Nicolau Horta Barbosa chefe... (17.12.1946), enviado ao agente do PI Francisco Horta (arquivo: Justiça Federal, Campo Grande); Of. 28, assinado por Acácio Arruda, agente... (29.12.1946), enviado a Nicolau Horta Barbosa, chefe... (arquivo: Justiça Federal...); Of. assinado por Acácio Arruda, agente... (14.01.1947), enviado a Nicolau Barbosa, chefe...; Carta assinada por Nicolau Horta Barbosa, chefe... (23.01.1947), enviada para Acácio Arruda, agente... (apud BEZERRA, 1994, p. 110); Of. 3, assinado por Acácio Arruda, agente... (01.02.1947), enviado a Nicolau Horta Barbosa, chefe... (apud BEZERRA 1994, p. 111-112); Of. 14, assinado por Nicolau Horta Barbosa, chefe... (29.01.1947), enviado para Acácio Arruda, agente... (apud BEZERRA, 1994, p. 111); Carta de Nicolau Horta Barbosa (03.02.1947), enviada ao diretor do SPI, Modesto Donatim. (MI/CDMI/F.22/p. 326, apud BEZERRA, 1994, p. 112); De Acácio Arruda, agente... (em 15.04.1947), enviado a Nicolau Horta Barbosa, chefe... (apud BEZERRA, 1994, p. 112-113); Of. 12, assinado por Acácio Arruda, agente... (15.04.1947), enviado ao Sr. Vlademiro Müler do Amaral (apud BEZERRA, 1994, p. 113); Of. 13, assinado por Acácio Arruda, agente... (15.04.1947), enviado ao Sr. Ruy Gomes, delegado de polícia de Dourados (arquivo: Justiça Federal...).
}

Espaço Ameríndio, Porto Alegre, v. 7, n. 2, p. 26-63, jul./dez. 2013. 
KATYA VIETTA - Histórias territoriais...

Prado - chefe da IR5-SPI - e Arnulfo Fioravante - agente do PI Francisco Horta (Reserva de Dourados) - se reuniram com Jorge Coutinho Aguirre - diretor da CAND - e definiram caber a CAND: reservar lotes (de 30 hectares cada) ocupados pelos índios, facultando-lhes o direito de dispor deles e de suas benfeitorias, mediante indenização; ceder aos índios 500 hectares contínuos, entre o rio Brilhante e o córrego Panambi. Na correspondência do SPI e da CAND se lê que o acordo também envolveu favores àqueles funcionários do SPI53.

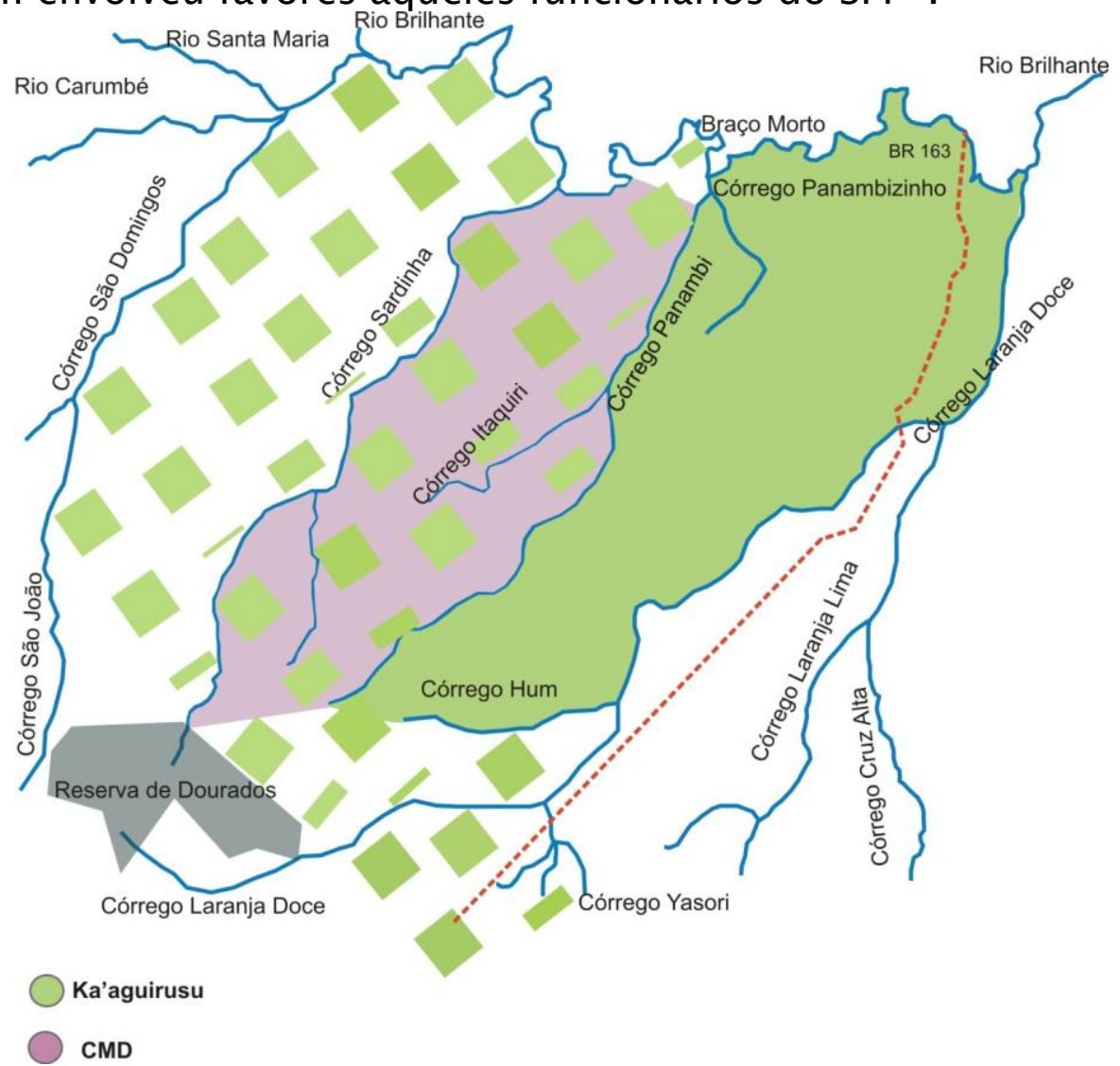

Figura 05: Os limites de Ka'aguirusu e da Colônia Municipal de Dourados ${ }^{54}$. Entre os Kaiowa não há consenso quanto aos limites sul e oeste de Ka'aguirusu, a área pontilhada indica o dissenso. A linha vermelha indica o traçado da BR 163 . De acordo com os Kaiowa, ele coincide com o traçado da linha telegráfica e de sua estrada de apoio.

Fonte: Para a CMD: Carli, 2005, p.128; para Ka'aguirusu: relatos kaiowa.

\footnotetext{
${ }^{53}$ Veja: Carta de Arnulfo Fioravante a Jorge Coutinho Aguirre. Dourados. 03.09.1947 (arquivo: Justiça Federal...); Of. 127, assinado por Jorge Coutinho Aguirre (04.09.1949), enviado para Arnulfo Fioravante (arquivo: Justiça Federal...).

${ }^{54} \mathrm{O}$ decreto estadual 616, de 20.01.1923 reservou para colonização uma área de 50.000 hectares entre o rio Brilhante e o córrego Panambi. Embora desde 1926 estas terras estivessem parcialmente ocupadas por posseiros, somente em 1946 a Colônia Municipal de Dourados (CMD) foi regulamentada. Devido ao seu rápido desenvolvimento, em 1953 a CMD foi elevada à categoria de município, com a designação Itaporã. Tal desenvolvimento foi largamente favorecido pela política varguista.
}

Espaço Ameríndio, Porto Alegre, v. 7, n. 2, p. 26-63, jul./dez. 2013. 
KATYA VIETTA - Histórias territoriais...

José Maria da Gama Malcher, chefe do Serviço de Orientação e Assistência (SOA-SPI), se posicionou contra o acordo55 e solicitou, através de Darcy Ribeiro, um parecer da Seção de Estudos (SE-SPI)56. Entre outras questões, Ribeiro informou que há muito Panambi (ou Ka'aguirusu) representa um sério problema a IR5 e recomendou procedimentos para a restauração da posse kaiowa57. Apesar dos esforços de setores do SPI, a CAND manteve o loteamento, não procedeu à cessão dos 500 hectares e, embora destinasse aos Kaiowa os lotes onde se localizavam as suas habitações, criou inúmeros expedientes para que estes thes fossem reintegrados, promovendo expulsões em cadeia58. Para os Kaiowa, estar inserido no projeto da CAND não era alternativa, assim, muitos abandonaram ou negociaram os lotes (ou suas benfeitorias), porém na maioria das vezes coagidos por colonos ou funcionários da CAND e do SPI.

Ao assumir a direção do SPI, em 1951, Malcher tomou medidas para demarcar 2.000 hectares entre os córregos Panambi, Laranja Doce

\footnotetext{
${ }^{55}$ Of. assinado por José Maria da Gama Malcher, chefe do SOA-SPI (25.08.49), enviado para Modesto Donatini Dias da Cruz, diretor do SPI.

${ }^{56}$ Veja: Of. de José Maria G. Malcher (30.08.1949), enviado para Modesto Donatini, diretor do SPI (apud BEZERRA, 1994, p.116 e 98-99).

${ }^{57}$ Ribeiro finaliza a sua argumentação dizendo que a CAND é tida pelos mato-grossenses como a "instituição oficial mais promissora no seu Estado", permitir que "esta obra de emancipação" seja feita a custa dos Kaiowa "seria um luxo de despotismo... tanto mais desumano porque partiria exatamente do órgão oficialmente responsável por sua proteção em nome da República". Assim, convida às autoridades do Ministério da Agricultura a mostrar aos Kaiowa que eles "devem se juntar a todos os que depositam suas esperanças no sentimento de justiça e no labor patriótico da Colônia Federal de Dourados". Relatório elaborado por Darcy Ribeiro (15.10.1949), enviado ao diretor do SPI (arquivo: Justiça Federal...).

58 Veja: Do PI Francisco Horta ao diretor da CAND (26.07.1950) (MI/CDMI/F.06/p.88, apud BEZERRA, 1994, p.118); M/M 31 Do inspetor José Pinto da Silva, ao administrador da CAND, Tácito Pace, em (4.11.1950) (apud BEZERRA, 1994, p.118); Relatório elaborado por Ilse Araújo de Souza, atendendo solicitação da $9^{\text {a }}$ Delegacia Regional-Funai, para a realização de estudos com vistas à demarcação de Panambi; Targa Moreira (1990, p. 86); M/M 35, de Alaor Fioravante, agente do PI Francisco Horta, a Francisco Henrique Fonseca, chefe IR5 (30.06.1953) (MI/CDMI/F.07/p.91, apud BEZERRA, 1994, p. 125); M/M 364, de Francisco Henrique Fonseca, chefe da IR5, enviado a Alaor Fioravante, PI... (08.07.1953); do chefe da IR5 (10.10.1961), ao encarregado do PI Francisco Horta... (MI/CDMI/F.06/p.83, apud BEZERRA, 1994, p. 127); - De Salatiel Diniz, agente do PI Francisco Horta (03.04.1962), ao Moacir Ribeiro Coelho, diretor do SPI (apud BEZERRA, 1994, p. 127-128); M/M 538 (4.12.1961), de José Mongenot, chefe substituto da IR5, enviado ao encarregado do PI Francisco Horta (apud MONTEIRO, 2003, p. 147); Of. 533, de Moacir Ribeiro Coelho, diretor do SPI (27.06.1962), ao chefe da IR 5 (apud BEZERRA, 1994, p. 93 e 128); Silva (1982, p.23); SPI. Radiotelegrama 300 (03.11.1963) (apud MONTEIRO, 2003, p. 148); Do agente do PI Francisco Horta, Salatiel Diniz (25.06.1964), ao chefe da IR5 MI/CDMI/F.07/p.97 (apud BEZERRA, 1994, p. 129).
}

Espaço Ameríndio, Porto Alegre, v. 7, n. 2, p. 26-63, jul./dez. 2013. 
KATYA VIETTA - Histórias territoriais...

e rio Brilhante ${ }^{59}$; procedimento semelhante se deu no início dos anos 1960, ambos sem êxito60. Em relatório de 1965, Salatiel Diniz, encarregado do PI Francisco Horta61, informou o que pode ser dito como o resultado de 19 anos de disputa entre CAND, SPI e os Kaiowa. Estes detinham cinco lotes (150 hectares) correspondentes a Panambi (-Lagoa Rica, Douradina) e dois lotes (60 hectares) onde se consolidou Panambizinho (Dourados). Dois pontos de resistência kaiowa conduzidos respectivamente pelas lideranças político-ritual Pa'i Chiquito Pedro e Joãozinho Karape. Entre 1967 e 1971, a IR562 e a 9a DR-Funai63 tomaram novas providências para demarcar estas terras ${ }^{64}$, porém, mais uma vez, sem conseguir interferir na força política vigente.

Assim como os projetos de governo anteriores, e também os posteriores, o projeto embutido na proposta de colonização varguista transformou terra em objeto de especulação financeira e política, atendendo interesses nem sempre legítimos. No atual Mato Grosso do Sul, em menos de 20 anos, a maior parte das terras kaiowa e guarani foram privatizadas 65 . O objetivo de transformar o núcleo da CAND em um centro urbano foi alcançado, do ponto de vista do contingente populacional e da produção econômica, pois Dourados rapidamente se

\footnotetext{
${ }^{59}$ Veja: Ordem de Serviço Interno 19 (26.05.1951), assinada por José Maria da Gama Malcher, diretor do SPI; - Relatório do auxiliar de inspetor Hélio Jorge Bucker (02.07.51), enviado para José Maria da Gama Malcher, diretor do SPI (arquivo: Justiça Federal...); Of. 587, assinado por José Maria G. Malcher (23.07.1951), enviado para Henrique Dietrich, diretor do Setor de Terras; Of. 4724/51 (06.08.1951), assinado por Tacito Pace, enviado ao diretor da ST-DTC; Do chefe da ST, Henrique Dietrich (10.08.1951), enviado para José Maria da G. Malcher, diretor do SPI (arquivo: Justiça Federal...); Do assistente jurídico, Dalmo Esteves de Almeida (10.09.1951), enviada ao diretor José Maria da Gama Malcher (apud BEZERRA, 1994, p. 120); Exposição do Chefe da IR5, Iridiano Amarinho de Oliveira (09.07.1952) (Mf 19 - Plan. 294, apud MONTEIRO, 2003, p. 126-129); Do assistente jurídico, ref. 31, Dalmo Esteves de Almeida (24.07.1952), enviado para José Maria G. Malcher, diretor do SPI (apud BEZERRA, 1994, p. 121); Of. de Eduardo Galvão, resp. p/exp. da SOA (05.08.52), enviado para José Maria Malcher, diretor do SPI; Of. 687, assinado por José Maria da Gama Malcher, diretor do SPI (07.08.1952), enviado ao diretor da Divisão de Terras e Colonização (apud BEZERRA, 1994, p. 122).

${ }^{60}$ Carta de Salatiel Diniz, chefe da IR5 (19.11.1963), enviada ao agente do PI Francisco Horta (MI/ CDMI/F.19/p.282, apud BEZERRA, 1994, p. 101e129).

${ }^{61}$ Relatório expondo levantamento realizado junto à aldeia Panambi, elaborado por Salatiel Marcondes Diniz, encarregado do PI Francisco Horta (09.01.1965), enviado ao Chefe da IR5 (apud MONTEIRO, 1994, p.149).

${ }^{62}$ De Salatiel Marcondes Diniz (30.11.1967), enviado para Helio Jorge Bucker, chefe da IR5 (apud MONTEIRO, 1994, p. 150).

${ }^{63}$ Of. 368/70, assinado por Hélio Bucker, delegado regional da $9^{\mathrm{a}}$ DR (15.12.1970), enviado a José Corbelino, procurador da Funai (apud BEZERRA, 1994, p. 132).

${ }^{64}$ A $9^{\text {a }}$ DR Funai contrata a empresa Topagri para realizar os estudos demarcatórios. O relatório foi entregue em fevereiro de 1971, de acordo com o Protocolo 187 - Ministério do Interior (BEZERRA, 1994, p. 133), definindo uma área de 2.037 hectares (Processo Funai 1.439/71).

${ }^{65}$ Ver: Vietta (2007, capítulos 1 e 3).
}

Espaço Ameríndio, Porto Alegre, v. 7, n. 2, p. 26-63, jul./dez. 2013. 
KATYA VIETTA - Histórias territoriais...

colocou como o segundo município do estado em ambos os aspectos. Mas Dourados também registra a maior concentração indígena do Mato Grosso do Sul, quase 20.000 Kaiowa, Guarani e Terena, na maioria, vivendo em absoluta pobreza66.

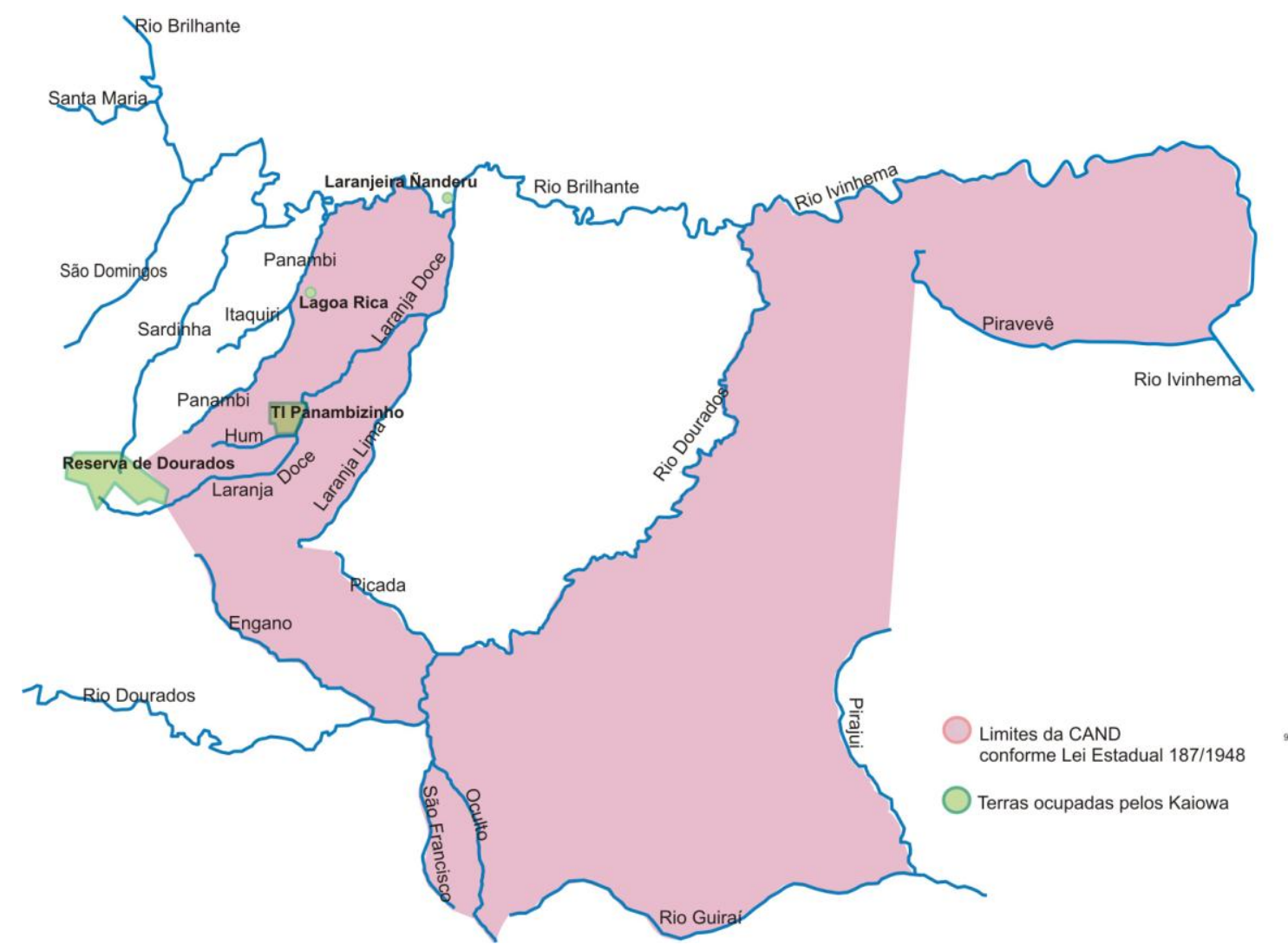

Figura 6 Terras ocupadas pela CAND.

O Estatuto do Índio, publicado em 1973, entre outras determinações, assegurou aos índios a posse permanente das terras por eles habitadas, independente da sua demarcação, e definiu um prazo de cinco anos para a conclusão dos processos demarcatórios pendentes. Este instrumento, igualmente, não foi suficiente para assegurar o direito kaiowa às terras de Ka'aguirusu e muitas outras localizadas no estado, situação que a Constituição de 1988 ainda não foi capaz de equacionar. A TI Panambizinho (1.284 hectares/323 habitantes $\left.{ }^{67}\right)$ foi homologada e

\footnotetext{
${ }^{66}$ Considero os habitantes da Reserva de Dourados, da TI Panambizinho, acampamentos em beira de estrada, além de dezenas de famílias que buscam alternativas habitacionais e de emprego nos espaços urbano e rurais, mas reconhecimento da sua condição como parte de uma destas etnias.

${ }^{67}$ Fonte: Siase - Funasa 2010.
}

Espaço Ameríndio, Porto Alegre, v. 7, n. 2, p. 26-63, jul./dez. 2013. 
KATYA VIETTA - Histórias territoriais...

totalmente ocupada em 2005. Panambi-Lagoa Rica permanece como ocupação irregular. Seus 832 habitantes, dispersos em escassos 366 hectares (VIETTA, 2011, p. 243), aguardam a expedição da portaria demarcatória de uma TI com 12.096 hectares. Muitas dezenas de parentelas oriundas de Ka'aguirusu permanecem reivindicando a demarcação de suas terras, parte significativa delas habitam a Reserva de Dourados (3.467 hectares/cerca de 14.000 habitantes) ou em acampamentos na beira das estradas.

Os dados aqui analisados mostram como regularizar posses adquiridas na contramão da legislação vigente, ao longo da historia do Brasil, foi muito mais fácil do que fazer cumprir a legislação que assegura os direitos indígenas. Em consequência, o Mato Grosso do Sul persiste em deter o pior quadro social e de distribuição de terras entre as populações indígenas brasileiras. Entretanto, as noções de "sertões" e principalmente de "terras devolutas", por muitos ainda difundidas, perdem a sua força à luz das narrativas kaiowa. Como afirmou Brasilino da Silva, um Kaiowa que faleceu em 2007, com 75 anos: "O governo tinha que saber bem: não pode vender nem um pedaço de terra que é do índio! Mas os civilizados montaram tudo!... Eles pensam que a gente é algum novato, que não sabe nada"!

\section{Referências bibliográficas}

ALMEIDA, Mario Monteiro de. Episódios Históricos da formação geográfica do Brasil. Campo Grande: Governo do Mato Grosso do Sul, [1951] 2010.

ALMEIDA, Rubem Thomaz de; MURA, Fabio. Historia y territorio entre los Guarani de Mato Grosso, Brasil. Revista de Indias, Madri, v. 64, n. 230, p. 55-66, 2004. Disponível http://revistadeindias.revistas.csic.es/index.php/revistadeindias/article/view/410/478 . Acesso em: 28 dez. 2013.

AMOROSO, Marta Rosa. Catequese e evasão: etnografia do Aldeamento Indígena São Pedro de Alcântara, Paraná (1855-1895). 1998. 207 f. Tese (Doutorado em Antropologia Social) - PPGAS, USP, São Paulo, 1998.

Espaço Ameríndio, Porto Alegre, v. 7, n. 2, p. 26-63, jul./dez. 2013. 
KATYA VIETTA - Histórias territoriais...

ARRUDA, Gilmar. Heródoto. In: Ciclo da erva mate em Mato grosso do Sul 1883-1947. Campo Grande: Instituto Euvaldo Lodi, 1986. p. 195-310.

- Frutos da Terra: os trabalhadores da Matte Larangeira. 1989. 233 f. Dissertação (Mestrado em História) - UNESP, Assis, SP, 1989.

ARRUDA, Lucybeth Camargo de. Cartografia nos postos de atração em Mato Grosso. In: SIMPÓSIO NACIONAL DE HISTÓRIA, 23, 2005, Londrina. Anais do XXIII Simpósio Nacional de História. Londrina: ANPUH, 2005. Disponível em: http://anpuh.org/anais/wp-content/uploads/mp/pdf/ANPUH.S23.1352.pdf. Acesso em: 28 dez. 2013.

ARRUTI, José Maurício Andion. Morte e vida do nordeste indígena: a emergência étnica como fenômeno histórico regional. Estudos Históricos, Rio de Janeiro, v. 8, n. 15, p. 57-94, 1995.

AYALA, S. Cardoso; SIMON, F. (Org.). Álbum Gráfico de Estado do Mato Grosso Tomo I, Tomo II e Tomo II. Campo Grande: Instituto Histórico e Geográfico De Mato Grosso do Sul, [1914], 2011.

AZANHA, Gilberto. A Lei de Terras de 1850 e as terras dos índios: ou da sua atualidade para a propositura de ações de nulidade de títulos expedidos por estados federados sobre terras de ocupação tradicional indígena. São Paulo: CTI, 2001. Disponível em: www.trabalhoindigenista.org.br/papers.asp . Acesso em: 28 dez. 2013.

BEZERRA, Marcos Otávio. Panambi: um caso de criação de uma Terra Indígena Kayowá. Niterói: EDUFF, 1994. (Coleção Cadernos de Graduação, 5).

BIANCHINI. Odaléia da Conceição Deniz. A Companhia Matte Larangeira e a ocupação da terra do sul de Mato Grosso (1880-1940). Campo Grande: UFMS, 2000.

BIGIO, Elias dos Santos. Linhas telegráficas e integração de povos indígenas: as estratégias políticas de Rondon (1889-1930). Brasília: CGDOC-FUNAI, 2003.

BRAND, Antônio. O impacto da perda da terra sobre a tradição Kaiowá/Guarani: os difíceis caminhos da palavra. 1997. 397 f. Tese (Doutorado História) - PGH-FFCH, PUC-RS, Porto Alegre, 1997.

CAMARGO, Isabel Camilo de O Sertão de Santana de Paranaíba: um perfil da sociedade pastoril-escravista no sul do antigo Mato Grosso (1830 - 1888). 2010. $232 \mathrm{f}$. Dissertação (Mestrado em História) - PPGH-UFGD, Dourados, MS, 2010.

A ocupação de Paranaíba no século XIX e a gênese do latifúndio na região. Trilhas da História, Três Lagoas, v. 1, n. 1, p. 52-63, jun./nov. 2011. Disponível em: http://www.trilhasdahistoria.ufms.br/artigos/isabelcamilo.pdf . Acesso em: $28 \mathrm{dez}$. 2013.

Espaço Ameríndio, Porto Alegre, v. 7, n. 2, p. 26-63, jul./dez. 2013. 
KATYA VIETTA - Histórias territoriais...

CARLI, Maria Aparecida Ferreira. A Colônia Agrícola Municipal de Dourados: colonização e povoamento: 1946-1956. 2005. 146 f. Dissertação (Mestrado em História) - PPGH-UFMS, Dourados, 2005.

CARNEIRO DA CUNHA. Manuela. Os direitos dos índios: ensaios e documentos. São Paulo: Brasiliense, 1987.

(Org.). Legislação Indigenista no século XIX: uma compilação: 1808-1889. São Paulo: EDUSP/Comissão Pró-Índio, 1992.

Xamanismo e Tradução. In: NOVAES, Adauto. In: A outra margem do Ocidente. São Paulo: MINC/Funart/Cia da Letras, 1999. p. 223-235.

CHAMORRO, Graciela. Etnografia do espaço: o "sertão" no relato de dois sertanistas do século XIX. In: GOETTERT, Jones Dari; MARSCHNER, Walter Roberto (Org.). Transfazer o espaço: ensaios de como a literatura vira espaço e vice versa. Dourados: UFGD, 2011. p. 107-128. Disponível em: www.ufgd.edu.br/editora/.../transfazer-oespaco-ensaio . Acesso em: 28 dez. 2013.

CORRÊA, Valmir Batista. Coronéis e bandidos em Mato Grosso (1889-1943). Campo Grande: UFMS, 1985.

Fronteira Oeste. Campo Grande: UFMS, 1999.

CORRÊA FILHO, Virgilio. Pedro Celestino. Rio de Janeiro: Zelio Valverde, 1945.

História de Mato Grosso. Rio de Janeiro: Instituto Nacional do Livro, 1969.

DALMOLIN, José Vicente. História de Nioaque. Nioaque, 2006. Disponível em: http://www.nioaqueonline.com.br/ . Acesso em: 28 dez. 2013.

Nossa gente, nossa terra e nossa história: um olhar para a cidadania. Guia Lopes da Laguna, 2011. Disponível em: http://nossaterranossagentenossahistoria.blogspot.com.br/ . Acesso em: 28 dez. 2013.

COUTINHO Jr. Valter Alves. Relatório sobre a Identificação e delimitação da TI Panambizinho. 177 p. - Portaria 1.154/93. Funai/DAF, Brasília março 1995.

DINIZ, Mônica. Sesmarias e posse de terras: política fundiária para assegurar a colonização brasileira. Histórica, v. 1, n. 2, n. p. jun. 2005. Disponível em: http://www.historica.arquivoestado.sp.gov.br/materias/anteriores/edicao02/materia03/.

Acesso em: 28 dez. 2013.

DORATIOTO, Francisco. Maldita Guerra. São Paulo: Cia da Letras, 2002.

ESSELIN. Paulo Marcos. A pecuária no processo de ocupação e desenvolvimento econômico do Pantanal sul-mato-grossense (1830-1910). 2003. 86 f. Tese (Doutorado em História) - PGH-FFCH, PUCRS, Porto Alegre, 2003.

Espaço Ameríndio, Porto Alegre, v. 7, n. 2, p. 26-63, jul./dez. 2013. 
KATYA VIETTA - Histórias territoriais...

FERREIRA, Francisco Bernardes; ROSA, Albino Pereira da. Maracaju e sua gente. Maracaju: [s.n.], 1988.

FRANCHETTO, Bruna; HECKENBERGER, Michel. Introdução: história e cultura xinguana. In: UFRJ, 2001. p. 7-18. (Org.) Os povos do Alto Xingu: história e cultura. Rio de Janeiro:

FREITAS JR., Augusto Teixeira. Terras e colonização. Rio de Janeiro: B. L. Garnier Livreiro, $1882 . \quad$ Disponível em: http://biblioteca.universia.net/html_bura/ficha/params/title/terrascolonisa . Acesso em: 28 dez. 2013.

GAGLIARD, José Mauro. $O$ indígena e a República. São Paulo: HUCITEC/EDUSP/SEC, 1989.

GALLOIS, Dominique Tilkin. O movimento na cosmologia Waiãpi: criação, expansão e transformação do universo. 1988. 362 f. Tese (Doutorado em Antropologia) - Dep. Antropologia Social. FFLCH-USP, São Paulo, 1988.

O Discurso Waiãpi sobre o ouro: um profetismo moderno. Revista de Antropologia, São Paulo, v. 30/31/32, p. 457-467, 1987/1988/1989.

Mairi revisistada: a integração da Fortaleza de Macapá na tradição oral dos Waiãpi. São Paulo: USP/FAPSPE, 1993.

"Nossas falas duras": discurso político e auto-representação Waiãpi. In: ALBERT, Bruce; RAMOS, Alcida (Org.). Pacificando o branco: cosmologias do contato no Norte-Amazônico. São Paulo: UNESP, 2002. p. 205-237.

Terras ocupadas? Territórios? Territorialidade? In: RICARDO, Fani (Org.).

Terras Indígenas e Unidades de Conservação da Natureza: o desfio das sobreposições. São Paulo: ISA, 2004. p. 37- 41.

Gêneses waiãpi, entre diversos e diferentes. Revista de Antropologia, São Paulo, v. 50, n. 1, p. 45-83, jan./jun. 2007.

GARCIA BARBOSA, Emílio. Os Barbosas em Mato Grosso. Campo Grande: IHGMS, [1961] 2011a.

Panoramas do sul de Mato Grosso. Campo Grande: IHGMS, [1961] 2011 b.

GARFIELD, Seth. As raízes de uma planta que hoje é o Brasil: os índios e o EstadoNação na era Vargas. Revista Brasileira de História, São Paulo, v. 20, n. 39, p. 15-42, 2000 . 
KATYA VIETTA - Histórias territoriais...

GOMES, Arlindo de Andrade. Município de Campo Grande: relatório apresentado à Câmara Municipal pelo Intendente-Geral Dr. Arlindo de Andrade Gomes, do ano de 1921. Campo Grande: Instituto Histórico e Geográfico de Mato Grosso do Sul, 2007.

GRESSLER, Lori Alice; SWENSSON, Lauro Jopperet. Aspectos históricos do povoamento e da colonização do Estado do Mato Grosso do Sul: destaque especial ao município de Dourados. São Paulo: Dag Gráfica/Editorial Ltda, 1988.

GUILLEN, Isabel Cristina Martins. A luta pela terra nos sertões de Mato Grosso. Estudos Sociedade e Agricultura, Rio de Janeiro, n. 12, p. 148-168, abr. 1999.

GUIMARÃES. Acyr Vaz. Mato Grosso do Sul: história dos municípios. Campo Grande: Instituto Histórico e Geográfico do Mato Grosso do Sul, 1992. v. 1.

Mato Grosso, sua evolução histórica. Campo Grande: UCDB, 1999.

HAVT, Nadja. Representações do ambiente e territorialidade entre os Zo'e/PA. 2001. 207 f. Dissertação (Mestrado em Antropologia Social) - PPGAS, FFLCH-USP, São Paulo, SP, 2001.

HECKENBERGER, Michel. Estrutura, história e transformação: a cultura xinguana na longeu durée, 1000-2000 D.C. In: FRANCHETTO, Bruna; HEKENBERGER, Michel (Org.). In: Os povos do Alto Xingu: história e cultura. Rio de Janeiro: UFRJ, 2001. p. 21-62.

HILL, Jonathan D. History, power and identity. Iowa City: University of Iowa Press, 1996.

HILL, Jonathan D. "Musicalizando o outro": ironia ritual e resistência étnica Wakuénai (Venezuela). In: ALBERT, Bruce; RAMOS, Alcida Rita (Org.). Pacificando o branco: cosmologias do contato Norte-Amazônico. São Paulo: Editora Unesp/Imprensa oficial do Estado, 2002, p. 348-374.

JOÃO, Izaque. Histórico de do Joãzinho Carapé Fernando. Documento produzido para a Escola Indígena Joãozinho Karapé Fernandes, Douradina, manuscrito, s/d, 07 p.

LADEIRA, Maria Inês. Espaço Geográfico Guarani-Mbya: significado, constituição e uso. 2001. 235 f. Tese (Doutorado em Geografia Humana) - PPGGH-FFLCH USP, São Paulo, 2001.

LENHARO, Alcir. Colonização e Trabalho no Brasil: Amazônia e Centro-Oeste. Campinas: UNICAMP, 1986.

LITTLE, Paul E. Espaço, memória e migração: por uma teoria da reterioalização. Textos de História, Brasília, , v. 2, n. 4, p. 5-25, 1994.

Superimposed cosmographies on regional amazonian frontiers. Brasília: UnB, 1997. (Série Antropologia, 219).

Espaço Ameríndio, Porto Alegre, v. 7, n. 2, p. 26-63, jul./dez. 2013. 
KATYA VIETTA - Histórias territoriais...

Territórios sociais e povos tradicionais no Brasil: por uma antropologia da territorialidade. Brasília: UnB, 2002. (Série Antropologia, 322).

LIMA, Antonio Carlos Souza. Um grande cerco de paz: poder tutelar, indianidade e formação do Estado no Brasil. Petrópolis: Vozes, 1995.

LOPES, Joaquim Francisco et al. Derrotas de Joaquim Francisco Lopes [1829-1857]: atualização e introdução de Hildebrando Campestrini. Campo Grande: IHGMS, 2007. (Série Relatos Históricos, 2).

MACIEL, Laura Antunes. A Comissão Rondon e a conquista ordenada dos sertões: espaço, telégrafo e civilização. Projeto História, São Paulo, v. 18, p. 167-189, maio 1999.

MALDI, Denise. A questão da territorialidade na etnologia brasileira. Revista Sociedade e Cultura, Goiania, v. 1, n. 1, p. 1-17, jan./jun. 1998.

De confederados a bárbaros: a representação da territorialidade e da fronteira indígenas nos séculos XVIII e XIX. Revista de Antropologia, São Paulo, v. 40, n. 2, p. 183-221, 1997.

MALDONADO, Caroline; BRAND, Antônio. A representação indígena guarani em livros memorialistas. Espaço Ameríndio, Porto Alegre, v. 4, n. 1, p. 31-43, jan./jun. 2010 .

MEIHY, José Carlos Sebe Bom. Canto de morte Kaiowá. São Paulo: Loyola, 1991.

MELIÁ, Bartomeu; GRÜNBERG, Georg; GRÜNBERG, Friedl. Los Paĩ-Taviterã: etnografía guaraní del Paraguay contemporáneo. Asunción: Centro de Estudios Antropológicos de la Universidad Católica, 1976.

MELIÁ, Bartomeu. El Guarani conquistado y reducido. Asunción: Centro de Estudios Antropologicos de la Universidad Catolica, 1985.

La tierra sin mal de los Guarani: economía y profecía. Suplemento Antropológico, Asunción, v. 22, n. 2, p. 491-507, dez. 1987.

Experiência religiosa Guarani. In: MERZAL, M. Et al (Org.). O rosto índio de deus. São Paulo: Vozes, 1989. p. 293-348.

MONTEIRO, John Manuel. Armas e armadilhas: história e resistência dos índios. In: NOVAES, Adauto (Org.). A outra margem do Ocidente. São Paulo: MINC/FUNART/Cia da Letras, 1999. p.237-249.

Tupis, Tapuias e historiadores: estudos de história indígena e do indigenismo. 2001. 233 f. Tese (Livre Docência) - UNICAMP, Campinas, 2001.

Espaço Ameríndio, Porto Alegre, v. 7, n. 2, p. 26-63, jul./dez. 2013. 
KATYA VIETTA - Histórias territoriais...

MONTEIRO, Maria Elizabeth Brêa. Levantamento histórico sobre os índios Guarani Kaiwá. Rio de Janeiro: Museu do Índio/Funai, 2003.

MOREIRA, Vânia Maria Losada. Terras indígenas do Espírito Santo sob o regime territorial de 1850. Revista Brasileira de História, São Paulo, v. 22 n. 43, p. 153-169, 2002.

MOTA, Lúcio Tadeu. As guerras dos índios Kaingang: a história épica dos Kaingang no Paraná (1769-1924). Maringá: UEM, 1994.

A Guerra de Conquista nos Territórios dos Índios Kaingang do Tibagi. Revista de História Regional, Ponta Grossa, v. 2, n. 1, p. 187-207, 1997.

As populações indígenas Kaiowá, Kaingang e as populações brasileiras na bacia dos rios Paranapanema/Tibagi no século XIX: conquista e relações interculturais. Fronteiras: Revista de História, Dourados, v. 9, n. 16, p. 47-72, jan./jul. 2007.

MURA, Fabio. À procura do "bom viver": território, tradição de conhecimento e ecologia doméstica entre os Kaiowa. 2006. 504 f. Tese (Doutorado em Antropologia Social) - PPGAS-UFRJ, Rio de Janeiro, 2006.

NIMUENDAJU, Curt Unkel. As lendas de criação e destruição do mundo como fundamentos da religião Apapocúva-Guarani. São Paulo: HUCITEC/EDUSP, 1987.

NOZOE, Nelson. Sesmarias e apossamento de terras no Brasil colônia. Revista EconomiA, Brasília, v. 7, n. 3, p. 587-605, set./dez. 2006.

OLIVEIRA FILHO, João Pacheco de (Org.). Indigenismo e territorialização: poderes, rotinas e saberes coloniais no Brasil contemporâneo. Rio de Janeiro: Contra Capa, 1998.

Ensaios em Antropologia histórica. Rio de Janeiro: UFRJ, 1999.

Ação indigenista e utopia milenarista: as múltiplas faces de um processo de territorilização entre os Ticuna. In: ALBERT, Bruce; RAMOS, Alcida (Org.). Pacificando o branco: cosmologias do contato no Norte-Amazônico. São Paulo: UNESP/Imprensa Oficial do Estado, 2002. p. 278-309.

Uma etnologia dos "índios misturados": situação colonial, territorialização e fluxos culturais. In: (Org.). A viagem de volta: etnicidade, política e reelaboração cultural no Nordeste indígena. Rio de Janeiro: Contra Capa/LACED, 2004. p. $13-42$.

OSÓRIO SILVA, Lígia Maria. Terra, direito e poder: o latifúndio improdutivo na legislação agrária brasileira. Boletim ABA, São Paulo, n. 27, p. 1-6, 1999.

OVERING, Joanna. O mito como história: um problema de tempo, realidade e outras questões. Mana, Rio de Janeiro, v. 1, n. 1, p. 107-140, out. 1995.

Espaço Ameríndio, Porto Alegre, v. 7, n. 2, p. 26-63, jul./dez. 2013. 
KATYA VIETTA - Histórias territoriais...

PACHECO, Roseli Aparecida Stefanes. Mobilizações Guarani Kaiowa e Ñandeva e a (re)construção de territórios (1978-2003): novas perspectivas para o direito indígena. 2004. 179 f. Dissertação (Mestrado em História) - PPGH-CEUD, UFMS, Dourados, MS, 2004.

PEREIRA, Levi Marques. Parentesco e organização social Kaiowá. 1999. 233 f. Dissertação (Mestrado em Antropologia Social) - Dep. Antropologia, IFCH/UNICAMP, Campinas, SP, 1999.

Relatório antropológico da Terra Indígena Kaiowá de Guyra Roka ou Ypitã - MS. 85 p., Funai, Brasília, 2001.

Imagens Kaiowá do sistema social e seu entorno. 2004. 430 f. Tese (Doutorado em Antropologia Social) - PPGAS-FFCH, USP, São Paulo, 2004.

Assentamentos e formas organizacionais dos Kaiowá atuais: o caso dos "índios de Corredor". Tellus, Campo Grande, v. 6, n. 10, p. 69-81, abr. 2006.

PERES, Sidnei. Terras Indígenas e ação indigenista no Nordeste (1910-67). In: OLIVEIRA FILHO, João Pacheco de (Org.). A viagem de volta: etnicidade, política e reelaboração cultural no Nordeste indígena. Rio de Janeiro: Contra Capa/LACED, 2004. p. 43-91.

QUEIROZ, Paulo Roberto Cimo. Condições econômicas do sul de Mato Grosso no início do século XX. Fronteiras, Campo Grande, v. 1, n. 2, p .113-136, 1997.

Uma ferrovia entre dois mundos: a Estrada de Ferro Noroeste do Brasil na primeira metade do século XX. Campo Grande/Bauru: UFMS/EDUSC, 2004.

Articulações econômicas e vias de comunicação do antigo sul de Mato Grosso (séculos XIX e XX). In: LAMOSO, Lisandra Pereira (Org.). Transportes e políticas públicas em Mato Grosso do Sul. Dourados: UFGD, 2008. p. 16-76.

RAFFESTIN, Claude. Por uma geografia do poder. São Paulo: Ática, 1993.

RODRIGUES, J. Barbosa. História de Mato Grosso do Sul. São Paulo: Editora do Escritor, 1984.

RONDON, Cândido Mariano da Silva. Relatório dos Trabalhos Realizados de 19001906. Rio de Janeiro: Comissão de linhas Telegráficas do Estado de Mato Grosso/Departamento de Imprensa Nacional, 1949.

ROSA Pedro Ângelo da. Resenha Histórica de Mato Grosso. Edição anotada por Hildebrando Campestrine. Campo Grande: IHGMS, 2004 [1962].

SABOYA, Vilma Eliza Trindade de. A lei de Terras e a política imperial: seus reflexos na Província de Mato Grosso. Revista Brasileira de História, São Paulo, v. 15, n. 30, p. 115-136, 1995.

Espaço Ameríndio, Porto Alegre, v. 7, n. 2, p. 26-63, jul./dez. 2013. 
KATYA VIETTA - Histórias territoriais...

SAHLINS, Marshall. Ilhas de História. Rio de Janeiro: Jorge Zahar Editores, 1990.

. Como pensam os nativos. São Paulo: EDUSP, 2001.

Adeus tristes tropos: a etnografia no contexto da moderna história mundial. In: Cultura na Prática. Rio de Janeiro: UFRJ, 2004. p. 503-534.

SALSA CORRÊA, Lúcia. História e Fronteira: o Sul de Mato Grosso 1870 - 1920. Campo Grande: UCDB, 1999.

A fronteira indígena no Sul de Mato Grosso: século XIX - Fontes comentadas Tellus, Campo Grande, v. 2, n. 2, p. 155-169, abr. 2002.

SCHADEN, Egon. Desenhos de índios Kayová-Guarani. Revista de Antropologia, São Paulo, v. 11, n. 1 e 2, p. 79-82, jun./dez. 1963.

Aculturação Indígena. São Paulo: Livraria Pioneira EDUSP, 1969.

Aspectos fundamentais da cultura Guarani. São Paulo: EPU/EDUSP, 1974.

SEGATO. Rita Laura. Em busca de léxico para teorizar a experiência territorial contemporânea. Brasília: UnB, 2005. (Série Antropologia, 373).

SILVA, Joana A. Fernandes. Os Kaiowá e a ideologia dos projetos econômicos. 1982. 141 f. Dissertação (Mestrado em Antropologia Social) - IFCH, UNICAMP, Campinas, 1982.

TARGA MOREIRA, Regina Heloiza. Memória fotográfica de Dourados. Campo Grande: UFMS, 1990.

TSCHIKEL Jr., René. Uma breve história dos índios Kaiowa e Guarani e a sua participação como trabalhadores nos ervais nativos da Companhia Matte Larangeira. 2005. 61 f. Monografia (Especialização em História Regional) - Dep. de História, UFMS, Aquidauana, MS, 2005.

TURNER, Terence. De cosmologia a História: resistência adaptação e consciência social entre os Kayapó. In: VIVEIROS DE CASTRO, Eduardo; CARNEIRO DA CUNHA, Manuela (Org.). Amazônia: etnologia e história indígena. São Paulo: NHIIUSP/Fapesp, 1993. p. 42-66.

VIETTA, Katya. Relatório final da Perícia realizada na Área Indígena de Panambizinho, Distrito de Panambi, Município de Dourados. 134 p. Processo 96158-8. Perícia realizada a pedido do Sr. Juiz Federal da I Vara de Seção Judiciária de Mato Grosso do Sul, 1998.

Espaço Ameríndio, Porto Alegre, v. 7, n. 2, p. 26-63, jul./dez. 2013. 
KATYA VIETTA - Histórias territoriais...

Tekoha e te'y guasu: algumas considerações sobre articulações políticas kaiowa e Guarani a partir das noções de parentesco e ocupação espacial. Tellus, Campo Grande, n. 1, p. 89-101, out. 2001.

Histórias sobre terras e xamãs kaiowa: territorialidade e organização social na perspectiva dos Kaiowa de Panambizinho (Dourados, MS). 2007. 513 f. Tese (Doutorado em Antropologia Social) - PPGAS-FFLCH, USP, São Paulo, 2007.

Relatório Circunstanciado de Delimitação e Identificação da Terra Indígena Panambi - Lagoa Rica (Douradina, MS). 440 p. Atendendo as Portarias Funai 232/PRES, de 17 de março de 2008, e $n^{0}$ 1760, de 10 de julho de 2008. FUNAI/Ministério da Justiça, Brasília 2011. 440 p.

Como o coletivo se transforma em privado: O histórico papel do Estado na privatização das terras indígenas sul-mato-grossenses. Palestra: Mesa Redonda do Tribunal Popular da Terra em Mato Grosso do Sul. Campo Grande: UFMS, mar. 2012a.

Histórias territoriais kaiowa: o histórico descompasso entre legislação e política fundiária. Anais da 28 ${ }^{a}$ Reunião Brasileira de Antropologia. GT15 Circunscrevendo fragmentos: debate sobre processos de reconhecimento de direitos territoriais séc XXI SP, julho de 2012 (b), 14 p.

Os Deuses, os homens e suas escolhas: cosmologia, organização social, conflitos territoriais e outras histórias kaiowa. In: COMBÈS, Isabelle; CHAMORRO, Graciela (Org.). Povos Indígenas no MS. Dourados: Ed. UFGD, 2012c. p. 1-25.

Relatório Circunstanciado de Delimitação e Identificação da Terra Indígena Laranjeira Nanderu (Rio Brilhante, MS). 440 p. (versão preliminar). Atendendo a Portaria Funai $\mathrm{n}^{0} 1.760$, de 10 de julho de 2008. FUNAI/Ministério da Justiça, Brasília 2013.

VIVEIROS DE CASTRO, Eduardo Batalha. Os termos da outra história. In: RICARDO, Carlos Alberto (Org.). Povos indígenas no Brasil 1996-2000. Rio de Janeiro: Instituto Socioambiental, 2000. p. 49-54.

VIVEIROS, Esther de. Rondon conta a sua vida. Rio de Janeiro: Livraria São José, 1958 .

WISSENBACH, Maria Cristina Cortez. Desbravamento e catequese na constituição da nacionalidade brasileira: as expedições do Barão de Antonina no Brasil Meridional. Revista Brasileira de História, São Paulo, v. 15, n. 30, p. 137-155, 1995.

Espaço Ameríndio, Porto Alegre, v. 7, n. 2, p. 26-63, jul./dez. 2013. 
KATYA VIETTA - Histórias territoriais...

Processos administrativos consultados

Processo Administrativo Funai/BSB/140/71 (Aldeia Panambi, Douradina, MS).

Processo Administrativo Funai /BSB/1148/82 (Aldeia Panambi, Douradina MS).

Ação Reivindicatória de Reintegração de posse n. 00737-4, autos n.0355/87 -V n. 0365/87 - V, apresentada por Tereza de Araújo Bagordachi e filhos (TI Panambzinho, Dourados, MS).

Processo Administrativo Funai /BSB/1602/95-13 (TI Panambizinho, Dourados, MS).

Espaço Ameríndio, Porto Alegre, v. 7, n. 2, p. 26-63, jul./dez. 2013. 